\title{
Water-Quality Assessment of the Rio Grande Valley, Colorado, New Mexico, and Texas--Fish Communities at Selected Sites, 1993-95
}

By Lisa F. Carter

U.S. GEOLOGICAL SURVEY

Water-Resources Investigations Report 97-4017

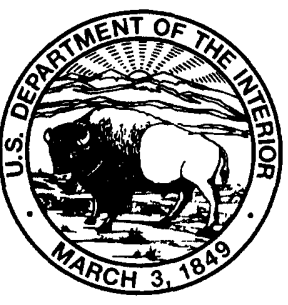




\section{U.S. DEPARTMENT OF THE INTERIOR \\ BRUCE BABBITT, Secretary}

U.S. GEOLOGICAL SURVEY

Gordon P. Eaton, Director

Any use of firm, trade, or brand names in this report is for identification purposes only and does not constitute endorsement by the U.S. Geological Survey.

For additional information write to:

District Chief

U.S. Geological Survey

Water Resources Division

4501 Indian School Road NE, Suite 200

Albuquerque, NM 87110-3929
Copies of this report can be purchased from:

U.S. Geological Survey

Branch of Information Services

Box 25286

Denver, CO 80225-0286

Information regarding the National Water-Quality Assessment (NAWQA) Program is available on the Internet via the World Wide Web. You may connect to the NAWQA Home Page using the Universal Resource Locator (URL) at:

$<$ http://wwwrvares.er.usgs.gov/nawqa/nawqa_home.html> 


\section{FOREWORD}

The mission of the U.S. Geological Survey (USGS) is to assess the quantity and quality of the earth resources of the Nation and to provide information that will assist resource managers and policymakers at Federal, State, and local levels in making sound decisions. Assessment of water-quality conditions and trends is an important part of this overall mission.

One of the greatest challenges faced by waterresources scientists is acquiring reliable information that will guide the use and protection of the Nation's water resources. That challenge is being addressed by Federal, State, interstate, and local water-resource agencies and by many academic institutions. These organizations are collecting water-quality data for a host of purposes that include: compliance with permits and water-supply standards; development of remediation plans for a specific contamination problem; operational decisions on industrial, wastewater, or watersupply facilities; and research on factors that affect water quality. An additional need for water-quality information is to provide a basis on which regional and national-level policy decisions can be based. Wise decisions must be based on sound information. As a society we need to know whether certain types of water-quality problems are isolated or ubiquitous, whether there are significant differences in conditions among regions, whether the conditions are changing over time, and why these conditions change from place to place and over time. The information can be used to help determine the efficacy of existing waterquality policies and to help analysts determine the need for and likely consequences of new policies.

To address these needs, the Congress appropriated funds in 1986 for the USGS to begin a pilot program in seven project areas to develop and refine the National Water-Quality Assessment (NAWQA) Program. In 1991, the USGS began full implementation of the program. The NAWQA Program builds upon an existing base of water-quality studies of the USGS, as well as those of other Federal, State, and local agencies. The objectives of the NAWQA Program are to:

- Describe current water-quality conditions for a large part of the Nation's freshwater streams, rivers, and aquifers.

-Describe how water quality is changing over time.

-Improve understanding of the primary natural and human factors that affect water-quality conditions.
This information will help support the development and evaluation of management, regulatory, and monitoring decisions by other Federal, State, and local agencies to protect, use, and enhance water resources.

The goals of the NAWQA Program are being achieved through ongoing and proposed investigations of 60 of the Nation's most important river basins and aquifer systems, which are referred to as study units. These study units are distributed throughout the Nation and cover a diversity of hydrogeologic settings. More than two-thirds of the Nation's freshwater use occurs within the 60 study units and more than two-thirds of the people served by public water-supply systems live within their boundaries.

National synthesis of data analysis, based on aggregation of comparable information obtained from the study units, is a major component of the program. This effort focuses on selected water-quality topics using nationally consistent information. Comparative studies will explain differences and similarities in observed water-quality conditions among study areas and will identify changes and trends and their causes. The first topics addressed by the national synthesis are pesticides, nutrients, volatile organic compounds, and aquatic biology. Discussions on these and other waterquality topics will be published in periodic summaries of the quality of the Nation's ground and surface water as the information becomes available.

This report is an element of the comprehensive body of information developed as part of the NAWQA Program. The program depends heavily on the advice, cooperation, and information from many Federal, State, interstate, Tribal, and local agencies and the public. The assistance and suggestions of all are greatly appreciated.
Robert M. Hirsch

Chief Hydrologist 



\section{CONTENTS}

Abstract

Introduction

Purpose and scope

Description of study area.

Acknowledgments

Methods of sampling and analysis.

Fish community sampling.

Analytical approach

Fish communities

Spatial pattern of community structure

Temporal pattern of community structure ...................................................................... 19

Summary

\section{FIGURES}

Figure 1. Map showing location of fish community sample sites, physiographic provinces, and ecoregions

2-5. Photographs showing:

2. The Saguache Creek near Saguache, Colorado, is within the San Luis Closed Basin and is representative of streams in the Southern Rocky Mountains physiographic province and the Southern Rocky Mountains ecoregion..

3. The Rio Grande below Taos Junction Bridge, near Taos, New Mexico, is representative of streams in the Southern Rocky Mountains physiographic province and the Arizona/New Mexico Plateaus ecoregion

4. The Rio Grande at El Paso, Texas, is representative of streams in the Basin and Range physiographic province and the Southern Deserts ecoregion.......

5. Electrofishing was the primary method of collecting fish

6-8. Maps showing:

6. Percentage of native and introduced fish from samples collected in 1994

7. Percentage of trophic groups of fish from samples collected in 1994.

8. Percentage of tolerant and intolerant fish from samples collected in 1994. 


\section{FIGURES--Concluded}

9-12. Graphs showing:

9. Relative abundance and total number of individual fish in samples collected from three reaches at sites 8T and 9M in 1995.

10. Mean daily discharge and interquartile range of mean daily discharge for period of record at selected sites in the Rio Grande Basin, 1993-95

11. Relative abundance and total number of individual fish in samples collected at selected sites in the Rio Grande Basin, 1993-95

12. Indicators of the biotic integrity of fish communities at selected sites in the Rio Grande Basin, 1993-95

\section{TABLES}

1. Site number, station name and number, elevation, and contributing drainage area for fish collection sites, and the number of reaches sampled per year in the Rio Grande Basin

2. Fish collected in the Rio Grande Basin, 1993-95 10

\section{CONVERSION FACTORS AND VERTICAL DATUM}

\section{Multiply}

foot $(\mathrm{ft})$

mile (mi)

square mile $\left(\mathrm{mi}^{2}\right)$
By

0.3048

1.609

2.590
To obtain

meter

kilometer

square kilometer

Sea level: In this report sea level refers to the National Geodetic Vertical Datum of 1929--a geodetic datum derived from a general adjustment of the first-order level nets of the United States and Canada, formerly called Sea Level Datum of 1929. 


\title{
WATER-QUALITY ASSESSMENT OF THE RIO GRANDE VALLEY, COLORADO, NEW MEXICO, AND TEXAS--FISH COMMUNITIES AT SELECTED SITES, 1993-95
}

\author{
By Lisa F. Carter
}

\begin{abstract}
Fish communities at 10 sites in the Rio Grande Basin were sampled during low-flow periods between 1993 and 1995 as part of the U.S. Geological Survey National Water-Quality Assessment Program. The ecology of fish communities is one of several lines of evidence used to characterize water-quality conditions. This report describes the fish communities at selected sites in the Rio Grande Basin and relates the structure of these fish communities to the physical and chemical characteristics of the streams. Twenty-nine species of fish representing 10 families were identified in 25 samples collected during this study. Species richness ranged from 1 to 13 .

Cluster analysis of the 25 samples collected during this study delineated four groups of sites that were based on the similarity of the fish communities. The first two groups were individual sites with low species richness. The third group contained the most samples, and the fourth group consisted of samples from the Rio Grande at Isleta, New Mexico, and the Rio Grande at El Paso, Texas. The shift in community structure of samples from group 3 to group 4 reflects changes from predominantly coldwater fishes to warmwater fishes.

Four metrics of biotic integrity (percentages of introduced individuals, omnivores, tolerant individuals, and anomalies) were used in this study to provide a broad overview of the community structure. The relative percentages of introduced species at the Rio Grande near Del Norte, Colorado; Saguache Creek near Saguache, Colorado; Rio Grande below Taos Junction Bridge, near Taos, New Mexico; and Rio Grande at Isleta are indicative of biological stress on the communities at these sites. The dominance of omnivores in samples from the Rio Grande below Taos Junction Bridge, near Taos; Rio Chama near Chamita, New Mexico; Rio Grande at Isleta; and Rio Grande at El Paso is an indication of environmental stress at these sites. In 1995, tolerant species account for the entire fish community at the Rio Grande at Isleta. In all samples the occurrence of anomalies was less than 2 percent of the individuals, with the exception of the sample from the Rio Grande at Isleta. On the basis of the relative percentages of introduced individuals, omnivores, tolerant individuals, and anomalies, the biotic integrity at the Rio Grande at Isleta appears to be the most impaired of all sites and shows indications of potential chemical and physical perturbations.

Fish communities from three reaches at the Santa Fe River above Cochiti Lake, New Mexico, and the Rio Grande at Isleta were sampled in 1995 to assess small-scale spatial patterns in the structure of fish communities. The spatial pattern at these sites might be associated with natural variability of the fish communities or with the presence of habitat features such as pools.
\end{abstract}


The total number of individuals and relative abundance in a sample varied at sites sampled yearly during this study. All sites, with the exception of the Rio Grande near Del Norte, had a decline in total number of individuals in a sample. The temporal decline in the total number of individuals at these site might be associated with the natural variability within the fish communities.

\section{INTRODUCTION}

The U.S. Geological Survey (USGS) National Water-Quality Assessment (NAWQA) Program is a multidisciplinary approach to defining the current status of and trends in the quality of the Nation's surface- and ground-water resources (Gilliom and others, 1995). In 1991, the Rio Grande Valley and 19 other study units were selected for initiation of an intensive study of water quality throughout the Nation. Physical, chemical, and biological data from stream reaches influenced by natural and anthropogenic factors allow for an integrated approach to characterizing surface-water quality within the Rio Grande Valley study unit.

The ecology of fish communities is one of several lines of evidence used to characterize water-quality conditions. Although natural variability within fish communities may be high they may still be a useful indicator of ecosystem health (Moyle, 1994). A fish community is a group of fish species that occupy the same general area and can be defined by its structural and functional relations. The structure of a fish community is characterized by the types of fish present; their relative abundances, life stages, and sizes; and their spatial and temporal distributions (Meador and others, 1993). Changes to physical and chemical characteristics of the stream can affect the fish community structure. These changes can be detected through repeated analysis of the total number of fish collected, functional groups, species diversity, and relative abundance (Wootton, 1990).

\section{Purpose and Scope}

This report describes fish communities at selected sites in the Rio Grande Valley study unit and relates the structure of these fish communities to the physical and chemical characteristics of the streams. Fish communities were sampled at 10 sites in the study unit from June 1993 through September 1995 (table 1). The influence of a stream's physical and chemical characteristics on the fish community was determined through regression, correlation, and multivariate statistical analysis, and community structure analysis.

\section{Description of Study Area}

The Rio Grande Valley study unit covers approximately 45,900 square miles in Colorado, New Mexico, and Texas (fig. 1). The Rio Grande crosses several climatological zones as it traverses about 750 stream miles from its headwaters in the San Juan Mountains in southwestern Colorado to El Paso, Texas. Climatic differences are extreme from the headwaters of the Rio Grande (alpine tundra) to the lower boundary of the study unit (Chihuahuan desert). Climatological characteristics and the environmental setting of the Rio Grande Valley study unit were described by Ellis and others (1993). 
Table 1.--Site number, station name and number, elevation, and contributing drainage area for fish collection sites, and the number of reaches sampled per year in the Rio Grande Basin

[Location of site numbers shown in figure 1; M, main-stem site; CB, San Luis Closed Basin site; T, main-stem tributary site; samples not collected; U, unsuccessful attempt to collect sample]

\begin{tabular}{|c|c|c|c|c|c|c|c|}
\hline \multirow{2}{*}{$\begin{array}{l}\text { Site } \\
\text { number }\end{array}$} & \multirow[b]{2}{*}{ Station name } & \multirow[b]{2}{*}{ Station number } & \multirow{2}{*}{$\begin{array}{c}\text { Ele- } \\
\text { vation } \\
\text { (feet } \\
\text { above } \\
\text { sea } \\
\text { level) }\end{array}$} & \multirow{2}{*}{$\begin{array}{l}\text { Contrib- } \\
\text { uting } \\
\text { drainage } \\
\text { area } \\
\text { (square } \\
\text { miles) }\end{array}$} & \multicolumn{3}{|c|}{$\begin{array}{c}\text { Number of reaches } \\
\text { sampled }\end{array}$} \\
\hline & & & & & 1993 & 1994 & 1995 \\
\hline $1 \mathrm{M}$ & $\begin{array}{l}\text { Rio Grande } \\
\text { near Del Norte, Colo. }\end{array}$ & 08220000 & 7,980 & 1,311 & 1 & 1 & 1 \\
\hline $2 \mathrm{CB}$ & $\begin{array}{l}\text { Saguache Creek } \\
\text { near Saguache, Colo. }\end{array}$ & 08227000 & 8,030 & 512 & 1 & 1 & 1 \\
\hline $3 \mathrm{CB}$ & $\begin{array}{l}\text { Medano Creek } \\
\text { near Mosca, Colo. }\end{array}$ & 374752105300801 & 8,450 & 15.3 & 1 & -- & - \\
\hline $4 \mathrm{~T}$ & $\begin{array}{l}\text { Conejos River } \\
\text { near Lasauses } \text { Colo. }\end{array}$ & 08249000 & 7,495 & 789 & 1 & - & - \\
\hline $5 \mathrm{M}$ & $\begin{array}{l}\text { Rio Grande } \\
\text { below Taos Junction } \\
\text { Bridge } \\
\text { near Taos, N. Mex. }\end{array}$ & 08276500 & 6,050 & 6,527 & - & 1 & 1 \\
\hline $6 \mathrm{~T}$ & $\begin{array}{l}\text { Rio Chama } \\
\text { near Chamita, N. Mex. }\end{array}$ & 08290000 & 5,653 & 3,044 & 1 & 1 & - \\
\hline $7 \mathrm{~T}$ & $\begin{array}{l}\text { Rito de los Frijoles } \\
\text { in Bandelier National } \\
\text { Monument, N. Mex. }\end{array}$ & 08313350 & 6,140 & 18.3 & 1 & 1 & 1 \\
\hline $8 \mathrm{~T}$ & $\begin{array}{l}\text { Santa Fe River } \\
\text { above Cochiti Lake, N. } \\
\text { Mex. }\end{array}$ & 08317200 & 5,505 & 228 & $\mathrm{U}$ & $\mathrm{U}$ & 3 \\
\hline $9 \mathrm{M}$ & $\begin{array}{l}\text { Rio Grande } \\
\text { at Isleta, N. Mex. }\end{array}$ & 08331000 & 4,896 & 14,537 & 1 & 1 & 3 \\
\hline $10 \mathrm{M}$ & $\begin{array}{l}\text { Rio Grande } \\
\text { at El Paso, Tex. }{ }^{1}\end{array}$ & 08364000 & 3,722 & 30,076 & -- & 1 & - \\
\hline
\end{tabular}

${ }^{1}$ Fish were collected from one reach during April and November 1994 and are considered separate samples 
EXPLANATION

ECOREGION--From Omemik, 1987

Southem Rockies

Arizona/New Mexico Plateaus

Arizona/New Mexico Mountains

Southem Deserts

PHYSIOGRAPHIC PROVINCE BOUNDARY--

From Fenneman, 1946

- - San luis Closed basin boundari

1M FISH COMMUNITY SAMPLE SITE AND NUMBER--Identifier refers to table 1
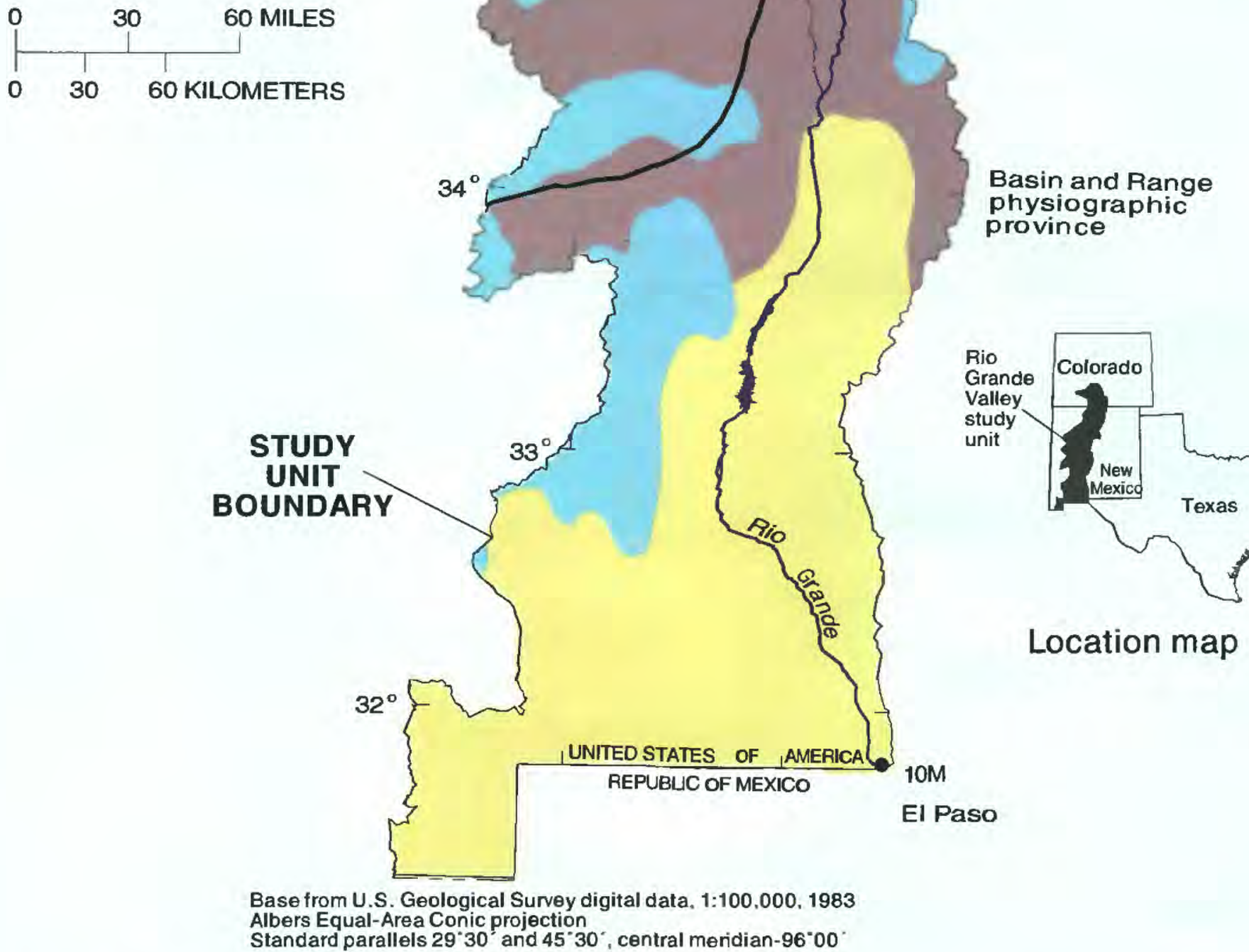

Figure 1.-- Location of fish community sample sites, physiographic provinces, and ecoregions. 
Various classifications have been applied to land areas in an attempt to identify homogeneous areas. Fenneman (1946) identified three major physiographic provinces in the Rio Grande Valley study unit (fig. 1): the Southern Rocky Mountains, Colorado Plateaus, and Basin and Range physiographic provinces. Physiographic provinces are distinct areas that have common topography, rock types and structure, and geologic and geomorphic history. Omernik (1987) identified four ecoregions in the study unit (fig. 1). Ecoregions are relatively homogeneous ecological regions and are classified by spatially variable combinations of geomorphology, soils, physiography, land use and cover, and potential natural vegetation. Saguache Creek near Saguache, Colorado, is within the San Luis Closed Basin and is representative of streams in the Southern Rocky Mountains physiographic province and the Southern Rocky Mountains ecoregion (fig. 2). The Rio Grande below Taos Junction Bridge, near Taos, New Mexico, is representative of streams in the Southern Rocky Mountains physiographic province and the Arizona/New Mexico Plateaus ecoregion (fig. 3). The Rio Grande at El Paso, Texas, is representative of streams in the Basin and Range physiographic province and the Southern Deserts ecoregion (fig. 4). Fish communities are thought to reflect the differences among the physiographic provinces and ecoregions of the study unit.

Main-stem reservoirs, diversions, and variable streamflow contributions from several tributaries alter streamflow of the Rio Grande and result in serial discontinuity (Ward and Stanford, 1983) rather than a river continuum (Vannote and others, 1980). Upstream from Del Norte, Colorado, several tributaries contribute inflow to the Rio Grande and there are relatively minor irrigation diversions. Near Del Norte significant irrigation diversions occur, and the majority of the water is diverted into the San Luis Closed Basin (fig. 1), which is separated from the Rio Grande by both a topographic divide and a ground-water divide. Sites were selected in the San Luis Closed Basin; waters draining either the San Juan Mountains north of Del Norte or the Sangre de Cristo Mountains north of Blanca Peak flow past these sites. Water from these drainages and water diverted from the main stem near Del Norte do not return directly to the Rio Grande. Additionally, during the irrigation season, streams draining the San Juan Mountains southwest of Alamosa, Colorado, and the Sangre de Cristo Mountains southeast of Alamosa are diverted, and little or no water reaches the Rio Grande. Ground-water discharge to the Rio Grande can be a substantial contribution to streamflow between the Colorado-New Mexico State line and Taos, New Mexico. Several perennial tributaries contribute surface water to the main stem between Taos and Cochiti Lake. Cochiti Lake consists of two arms, the Rio Grande and Santa Fe River, which are connected by a conveyance channel. The Santa Fe River does not flow directly to the Rio Grande when the elevation of Cochiti Lake is below 5,355 feet (Blanchard, 1993). Two main-stem reservoirs are located between Albuquerque, New Mexico, and El Paso, Texas, and several intermittent streams in this area can contribute flow to the Rio Grande. The effects of variable discharges, diversions, and sources of water in the Rio Grande are critical environmental influences on fish communities.

\section{Acknowledgments}

Fish communities were sampled with the assistance of individuals from the U.S. Fish and Wildlife Service, Colorado Division of Wildlife, New Mexico Department of Game and Fish, Texas Natural Resources Conservation Commission, New Mexico Highlands University, and USGS. Special thanks are extended to Steven Frenzel for his technical assistance in data analysis and his informal review of the manuscript. Additional thanks go to Joel Lusk of the U.S. Fish and Wildlife Service and C. Evan Hornig, who provided technical reviews of this report. 


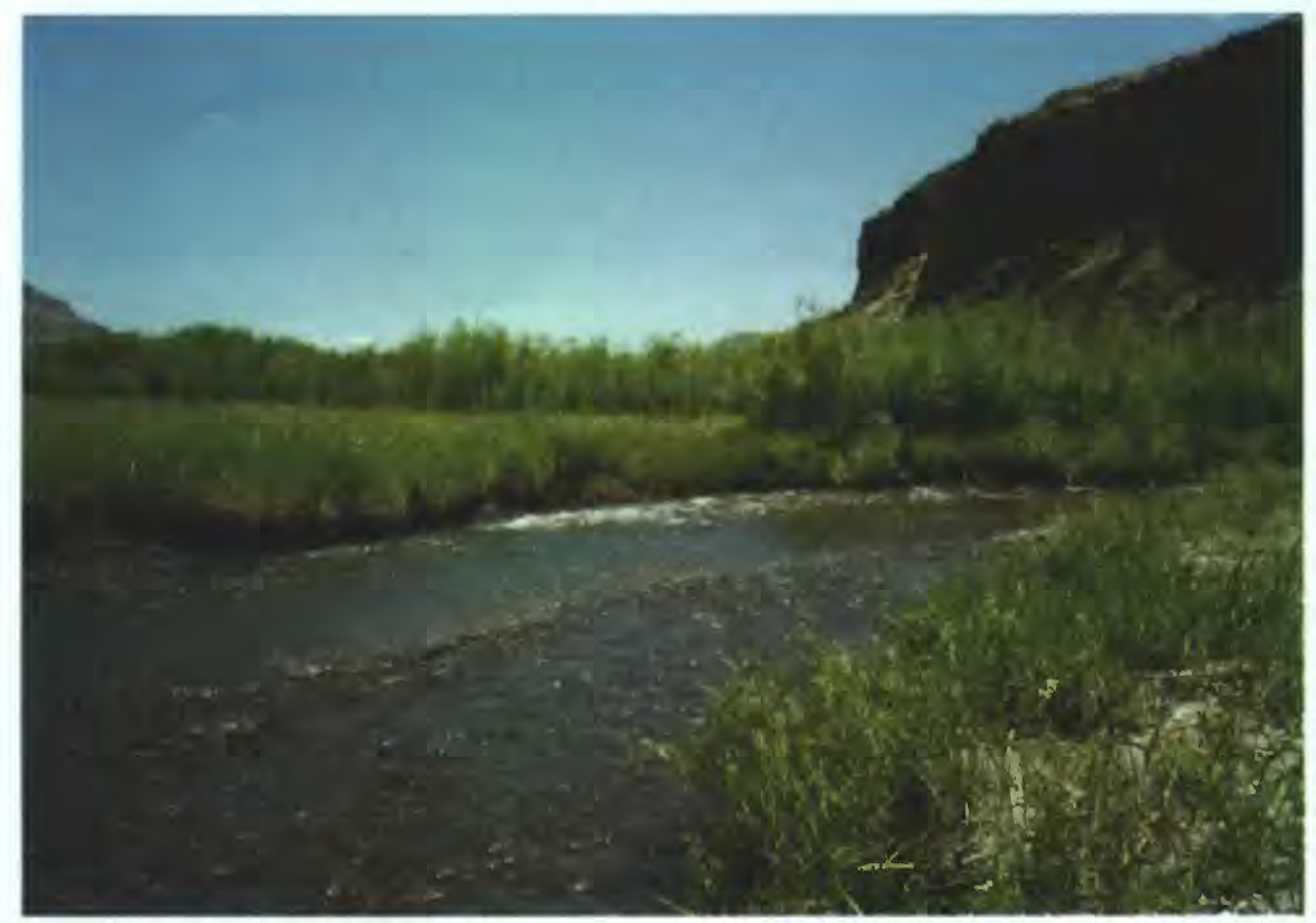

Figure 2.--Saguache Creek near Saguache, Colorado, is within the San Luis Closed Basin and is representative of streams in the Southem Rocky Mountains physiographic province and the Southem Rocky Mountains ecoregion. Photograph by L.M. Bexfield.

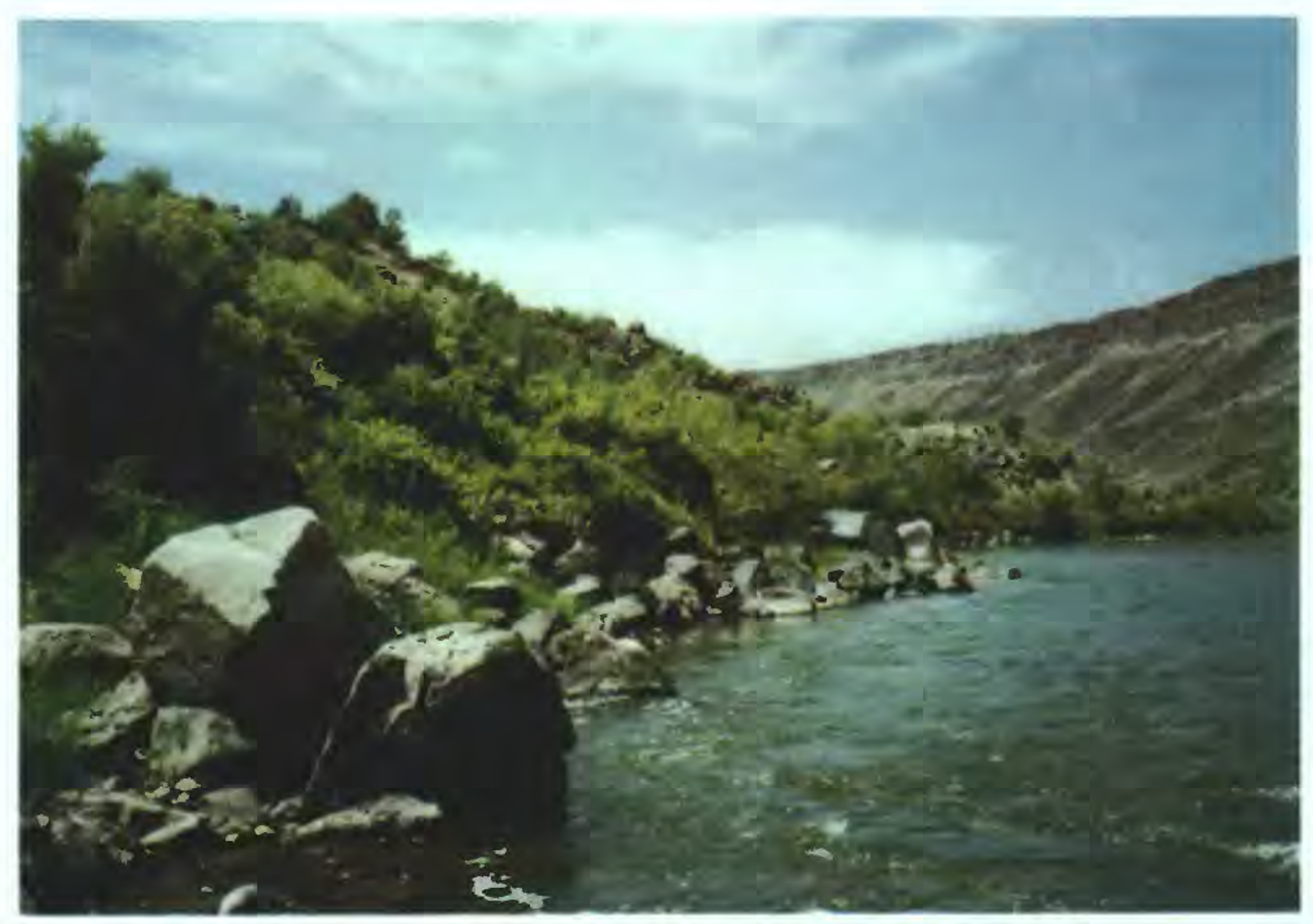

Figure 3.--The Rio Grande below Taos Junction Bridge, near Taos, New Mexico, is representative of streams in the Southem Rocky Mountains physiographic province and the Arizona/ New Mexico Plateaus ecoregion. Photograph by L.M. Bexfield. 


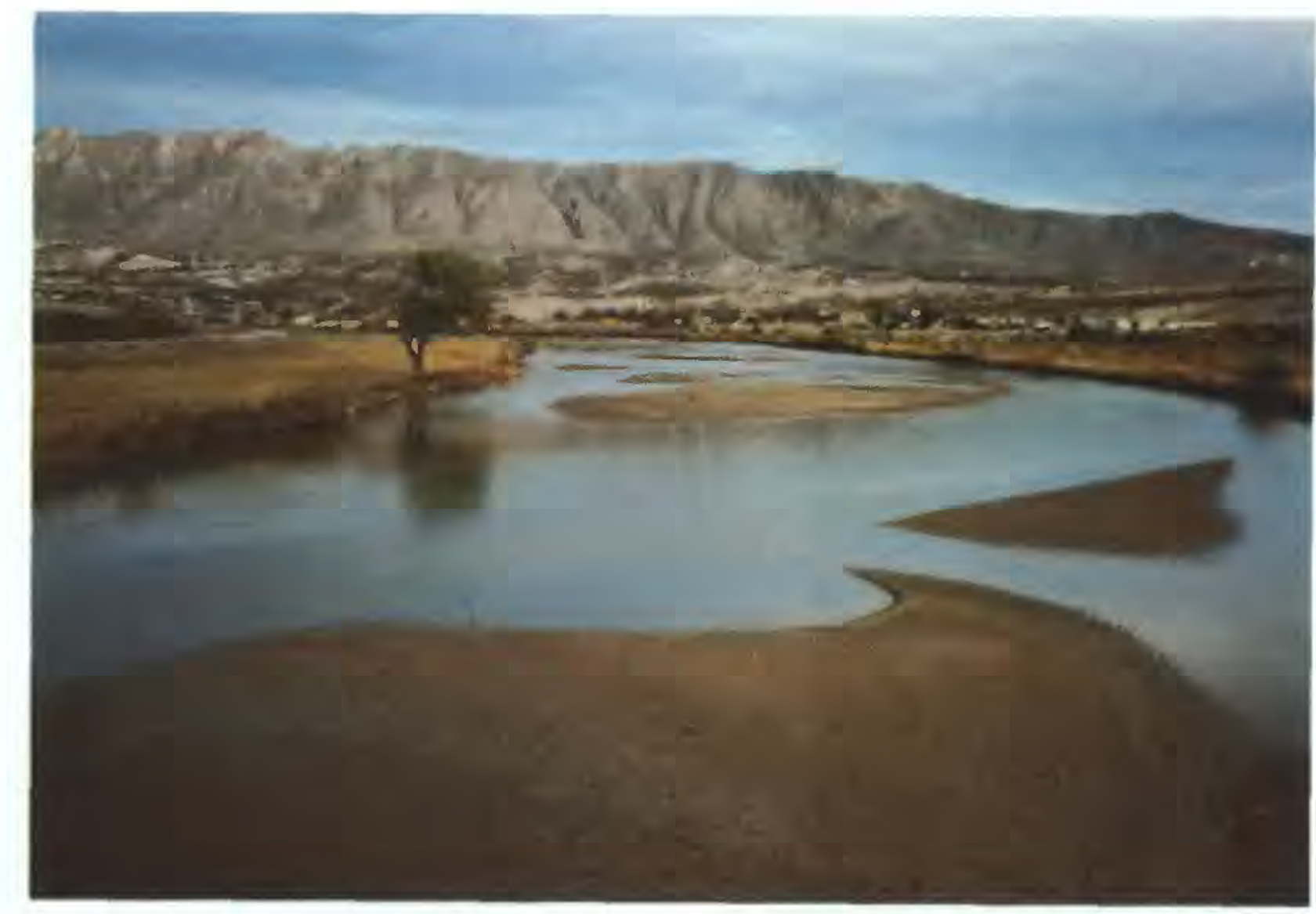

Figure 4.--The Rio Grande at El Paso, Texas, is representative of streams in the Basin and Range physiographic province and the Southern Deserts ecoregion. Photograph by S.D. Porter.

\section{METHODS OF SAMPLING AND ANALYSIS}

Fish samples were collected from four main-stem sites, four main-stem tributary sites, and two sites in the San Luis Closed Basin (fig. 1, table 1). Sites were identified numerically from 1 to 10 , followed by the alphabetical distinction of main stem (M), main-stem tributary (T), or San Luis Closed Basin (CB).

\section{Fish Community Sampling}

A reach, or section of stream, was selected to describe the fish community structure that best represents the condition of the larger river segment (Meador and others, 1993). Each reach was approximately 100 to 300 meters long and was selected on the basis of habitat diversity that included at least two habitat types (riffles, pools, and runs). If a reach was homogeneous with respect to habitat type, then the length of the reach was 20 times the channel width. One reach was selected at each site, except at sites $8 \mathrm{~T}$ and 9M. In 1995 three reaches, at least 300 meters apart, were selected at sites $8 \mathrm{~T}$ and $9 \mathrm{M}$ to determine instream variability of fish communities and physical and chemical characteristics between reaches. At sites $8 \mathrm{~T}$ and $9 \mathrm{M}$, the three reaches were identified from upstream to downstream as A, B, and C. All fish collected at a particular reach during a single sampling event were considered one sample.

The fish communities at 10 sites in the study unit were sampled between 1993 and 1995 (fig. 1; table 1). Most samples were collected each year during the summer low flow period (June-September). At site 10M samples were collected during April and November 1994. Samples could not be collected at each site during each sampling season because of prohibition of access, local restrictions or unacceptable sampling conditions such as high flow, or turbid waters. During the 1993 and 1994 sampling seasons, attempts to collect samples at site 8T were unsuccessful because high flow and turbid waters reduced visibility. 
Collection and processing of samples followed the protocols described by Meador and others (1993). Although various methods can be used to sample fish, electrofishing was the primary method used in this study because of its greater applicability and efficiency. A backpack and barge electrofishing units were used at wadeable sites, and a raft (fig. 5) was used at nonwadeable sites. Seining also was used as a supplementary method when local conditions warranted its use. All captured fish were identified to the species level with the exception of one specimen (Lepomis sp.) collected at site 10M (November 1994). Weight and length of most fish were determined, and external anomalies such as eroded fins, tumors, and external parasites were noted before fish were returned to the stream. A limited number of fish were retained for taxonomic verification and are archived at the USGS National Water Quality Laboratory in Arvada, Colorado.

\section{Analytical Approach}

Biologists have used several approaches to relate data on fish communities to environmental conditions. One approach is statistically based. Regression analysis can be used to determine which environmental characteristics (physical and chemical) are related to species richness at a site. Principal component analysis (PCA) can be used to determine the overall variance in the combination of various physical and chemical characteristics. Cluster analysis of samples, using the computer program TWINSPAN (Hill, 1979), groups sites according to the similarity of the fish communities. Spearman rank correlation and regression analysis can be used to determine which environmental characteristics resulting from PCA were related to the relative abundance of fish in the groups derived from the cluster analysis.

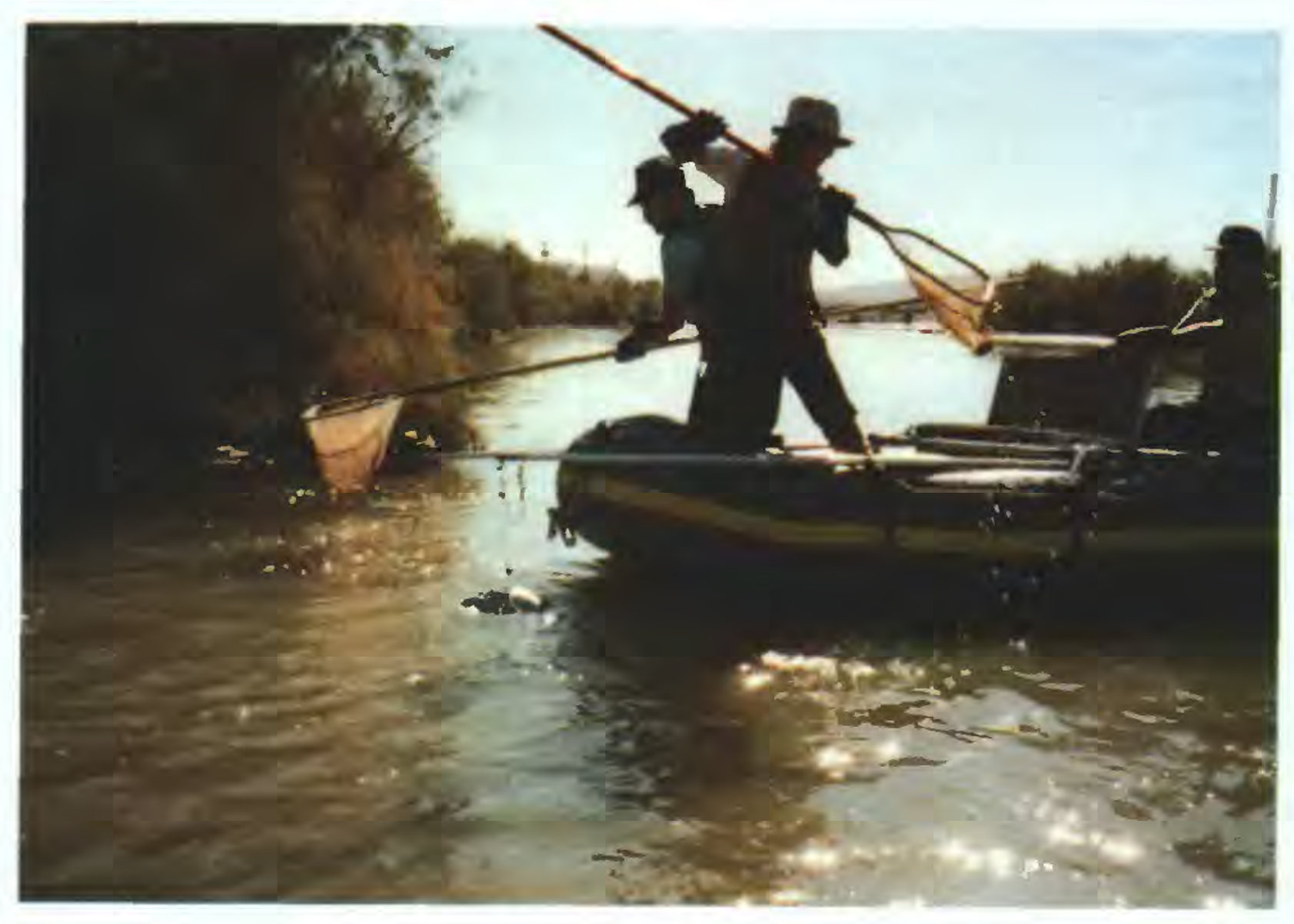

Figure 5.--Electrofishing was the primary method of collecting fish. Photograph by S.D. Porter. 
A second approach uses community structure characteristics, or "metrics," to assess environmental conditions. Two methods of determining the biotic integrity have been proposed by other investigators to evaluate the biological condition of rivers and streams. The index of well being incorporates two abundance and two diversity metrics (Gammon, 1980). The index of biotic integrity combines 12 metrics classified into three groups: species composition, trophic composition, and fish abundance and condition (Karr, 1981; Karr and Dudley, 1981; and Karr and others, 1986). The metrics of both indices are designed to relate the conditions of an existing community to that of a reference or relatively unaffected community. Each metric is given a rating and the biotic index value is the sum of the ratings for all the metrics. Specific metrics need to be adjusted for each region where indices will be applied; however, the applicability of these indices to the composition of fish communities (number of species and families) in the Rio Grande Basin has not been tested.

Because the scope of this study did not include development of a basin-specific index of biotic integrity, only four broadly applicable metrics (percentages of introduced individuals, omnivores, tolerant individuals, and anomalies) proposed by Karr (1981) were used to provide an overview of community structure and biotic integrity in the Rio Grande Basin. Individual fish were grouped by (1) species origin, (2) trophic group, and (3) tolerance to water quality or habitat degradation on the basis of classifications established by Plafkin and others (1989), Sublette and others (1990), and S.P. Platania (University of New Mexico, oral commun., 1996). On the basis of origin a fish species is considered either native or introduced. Although introduced species are an integral component of the fish community, the presence of introduced fish species is viewed as a disturbance to a stream because of the deviation from the expected community structure (Bramblett and Fausch, 1991). Some of the disturbances associated with introduced species are increased competition, predation, and displacement of native species. Trophic groups (predator, omnivore, generalist, insectivore, or herbivore) are based on the primary method a fish species acquires food. The trophic composition of a community is evaluated by the transition toward more generalized feeding strategies that typically occur with increased degradation of physicochemical habitat (Plafkin and others, 1989). Omnivores in particular are physiologically adapted to consume and utilize significant quantities of both plant and animal material, including detritus. Omnivores tend to dominate fish communities as specific components of the food base become less reliable (Karr and others, 1986). In this study, fish were classified as either tolerant or intolerant. Fish that are tolerant to various chemical and physical perturbations are found at a higher frequency at lower quality sites, and intolerant species being the first to disappear after a disturbance (Plafkin and others, 1989). The percentage of individuals having anomalies is an indication of environmental stress. At relatively unimpaired sites the percentage of individuals with anomalies is commonly low, whereas at sites downstream from point sources and in reaches that are impaired the percentage of anomalies can be high (Plafkin and others, 1989).

\section{FISH COMMUNITIES}

Twenty-nine species of fish representing 10 families were identified in 25 samples collected during this study (table 2). Species richness, a measure of diversity that refers to the number of different species in a sample, community, or habitat, ranged from 1 to 13 . The number of species in a sample are related to the contributing drainage area at each site. Species richness increased with increasing contributing drainage area $\left(r^{2}=0.92\right)$. Shelton (1968), Goldstein (1981), and Platania (1991) reported similar increases in species richness with the downstream succession of a river system's fish community. 
Table 2.--Fish collected in the Rio Grande Basin, 1993-95

[Site number location shown in figure 1. Native fish based on Sublette and others, 1990, and Platania, 1991 (shaded area). M, main-stem site; $\mathrm{CB}$, San Luis Closed Basin site; T, main-stem tributary site;

O, omnivore; $\mathrm{H}$, herbivore; I, insectivore; $\mathrm{P}$, predator; $\mathrm{G}$, generalist. +, fish present]

\begin{tabular}{|c|c|c|c|c|c|c|c|c|c|c|c|c|c|}
\hline \multirow{2}{*}{$\begin{array}{c}\text { Scientific name } \\
\text { by family }\end{array}$} & \multirow[b]{2}{*}{ Common name } & \multirow{2}{*}{$\begin{array}{l}\text { Trophic } \\
\text { group }^{1}\end{array}$} & \multirow{2}{*}{ Tolerance $^{2}$} & \multicolumn{10}{|c|}{ Site number } \\
\hline & & & & $1 \mathrm{M}$ & $2 \mathrm{CB}$ & $3 \mathrm{CB}$ & $4 \mathrm{~T}$ & $5 \mathrm{M}$ & $6 \mathrm{~T}$ & $7 \mathrm{~T}$ & $8 T^{3}$ & $9 \mathrm{M}^{4}$ & $10 \mathrm{M}^{5}$ \\
\hline Clupeidae & Herrings & & & & & & & & & & & & \\
\hline Dorosoma cepedianlum & Gizzard shad & $\mathrm{O}$ & Intolerant & & & & & & & & & & + \\
\hline Cyprinidae & Carps and minnows & & & & & & & & & & & & \\
\hline Cyprinella lutrensis & Red shiner & $\mathrm{O}$ & Tolerant & & & & + & & & & & + & + \\
\hline Cyprinus carpio & Common carp & $\mathrm{O}$ & Tolerant & & & & + & + & + & & & + & + \\
\hline Gila pandora & Rio Grande chub & 0 & Intolerant & & + & & & + & + & & & & \\
\hline Hybognathus amarus & Rio Grande silvery minnow & $\mathrm{H}$ & Intolerant & & & & & & & & & + & \\
\hline Pimephales promelas & Fathead minnow & $\mathrm{O}$ & Tolerant & + & + & & + & & + & & + & + & + \\
\hline Pimephales vigilax & Bullhead minnow & $\mathrm{O}$ & Tolerant & & & & & & & & & & + \\
\hline Platygobio gracilis & Flathead chub & I & Tolerant & & & & & & + & & + & + & \\
\hline Rhinichthys cataractae & Longnose dace & I & Intolerant & + & + & & + & + & + & & & + & \\
\hline Catostomidae & Suckers & & & & & & & & & & & & \\
\hline Carpiodes carpio & River carpsucker & 0 & Tolerant & & & & & & + & & & + & + \\
\hline Catostomus commersoni & White sucker & $\mathrm{O}$ & Tolerant & + & + & & + & + & + & & & + & \\
\hline Catostomus plebeius & Rio Grande sucker & $\mathrm{H}$ & Intolerant & & & & & + & + & & + & + & \\
\hline Esocidae & Pikes & & & & & & & & & & & & \\
\hline Esox lucius & Northern pike & $\mathbf{P}$ & Intolerant & & & & + & & & & & & \\
\hline Salmonidae & Trouts & & & & & & & & & & & & \\
\hline Onchorynchus clarki & Rio Grande cutthroat trout & I & Intolerant & & & + & & & & & & & \\
\hline Onchorynchus mykiss & Rainbow trout & I & Intolerant & + & + & & & + & & + & & & \\
\hline Salmo trutta & Brown trout & I & Intolerant & + & + & & + & + & + & & & & \\
\hline Salvelinus fontinalis & Brook trout & I & Intolerant & & & & & & & + & & & \\
\hline Ictaluridae & Bullhead catfishes & & & & & & & & & & & & \\
\hline Amiurus natalis & Yellow bullhead & I & Tolerant & & & & & & & & & + & \\
\hline Ictalurus punctatus & Channel catfish & $\mathrm{G}$ & Tolerant & & & & & & & & & + & + \\
\hline Pylodictis olivaris & Flathead catfish & $P$ & Tolerant & & & & & & & & & & + \\
\hline
\end{tabular}


Table 2.--Fish collected in the Rio Grande Basin, 1993-95 (Continued)

[Site number location shown in figure 1. Native fish based on Sublette and others, 1990, and Platania, 1991 (shaded area). M, main-stem site; $\mathrm{CB}$, San Luis Closed Basin site; $T$, main-stem tributary site;

$\mathrm{O}$, omnivore; $\mathrm{H}$, herbivore; I, insectivore; $\mathrm{P}$, predator; $\mathrm{G}$, generalist. +, fish present]

\begin{tabular}{|c|c|c|c|c|c|c|c|c|c|c|c|c|c|}
\hline \multirow{2}{*}{$\begin{array}{c}\text { Scientific name } \\
\text { by family }\end{array}$} & \multirow[b]{2}{*}{ Common name } & \multirow{2}{*}{$\begin{array}{l}\text { Trophic } \\
\text { group }^{1} \\
\end{array}$} & \multirow{2}{*}{ Tolerance $^{2}$} & \multicolumn{10}{|c|}{ Site number } \\
\hline & & & & $1 \mathrm{M}$ & $2 \mathrm{CB}$ & $3 \mathrm{CB}$ & $4 \mathrm{~T}$ & $5 \mathrm{M}$ & $6 \mathrm{~T}$ & $7 \mathrm{~T}$ & $8 T^{3}$ & $9 M^{4}$ & $10 \mathrm{M}^{5}$ \\
\hline Poeciliidae & Livebearers & & & & & & & & & & & & \\
\hline Gambusia affinis & Western mosquitofish & I & Tolerant & & & & & & & & + & + & \\
\hline Gasterosteidae & Sticklebacks & & & & & & & & & & & & \\
\hline Culaea inconstans & Brook stickleback & I & Intolerant & + & & & & & & & & & \\
\hline Percichthyidae & Temperate basses & & & & & & & & & & & & \\
\hline Morone chrysops & White bass & $\mathrm{P}$ & Intolerant & & & & & & & & & & + \\
\hline Centrarchidae & Sunfishes & & & & & & & & & & & & \\
\hline Lepomis cyanellus & Green sunfish & I & Tolerant & & & & & & & & + & & \\
\hline Lepomis macrochirus & Bluegill & I & Intolerant & & & & & & & & & & + \\
\hline Lepomis megalotis & Longear sunfish & I & Intolerant & & & & & & & & & & + \\
\hline Lepomis sp. & Sunfish species & I & & & & & & & & & & & + \\
\hline Micropterus dolomieu & Smallmouth bass & $\mathbf{P}$ & Intolerant & & & & & + & & & & & \\
\hline Micropterus salmoides & Largemouth bass & $\mathbf{P}$ & Intolerant & & & & & & & & & & + \\
\hline Pomoxis annularis & White crappie & I & Intolerant & & & & & & & & & + & \\
\hline Total species & & & & 6 & 6 & 1 & 7 & 8 & 9 & 2 & 5 & 13 & 13 \\
\hline Total omnivores & & & & 2 & 3 & 0 & 4 & 3 & 5 & 0 & 1 & 5 & 6 \\
\hline $\begin{array}{l}\text { Total tolerant } \\
\text { individuals }\end{array}$ & & & & 2 & 2 & 0 & 4 & 2 & 4 & 0 & 4 & 9 & 7 \\
\hline
\end{tabular}

${ }^{1}$ Plafkin and others, 1989; Sublette and others, 1990; S.P. Platania, University of New Mexico, oral commun., 1996

${ }^{2}$ Plafkin and others, 1989; S.P. Platania, University of New Mexico, oral commun., 1996

${ }^{3}$ Fish collected from multiple reaches during 1995

${ }^{4}$ Fish collected from a single reach during 1993 and 1994 and from multiple reaches during 1995

${ }^{5}$ Fish collected during April and November 1994 
In a compilation of historical records Sublette and others (1990) report 60 species of fish extant to the Rio Grande Basin in New Mexico have been identified. Species reported in northern New Mexico also range into Colorado; additionally, the cyprinid tench (Tinca tinca) is found in isolated lakes and reservoirs of the Rio Grande Basin in Colorado (Woodling, 1985). Therefore, the species reported in Sublette and others (1990) is considered to be the most complete list of species in the study area. All fish species collected during this study were listed in Sublette and others (1990), although only about half the species reported by Sublette and others were identified. The smaller number of species collected in this study than in the list of Sublette and others is attributed to the multidecade sampling at a larger regional scale on which the compilation of Sublette and others (1990) is based.

Forty-six physical and chemical characteristics were normalized before using PCA to create a subset of variables that explained most of the variance among sites. Physiographic province and ecoregion were the physical variables, and specific conductance, alkalinity, hardness, dissolved solids, sulfate, chloride, and ammonia plus organic nitrogen were the chemical variables that explained most of the variance among sites.

Cluster analysis using the relative abundance of fish (percentage of the total number of individuals) in the 25 samples collected during this study delineated four groups of sites that were based on the similarity of the fish communities. Species richness was low at sites $3 C B$ (group 1) and 7T (group 2). Group 3 contained the most samples and included sites 1M, 2CB, 4T, $5 \mathrm{M}, 6 \mathrm{~T}$, and $8 \mathrm{~T}$. The presence and relative abundance of brown trout, fathead minnow, and white sucker appear to have the greatest influence on the grouping of these sites. Group 4 consisted of samples from sites $9 \mathrm{M}$ and $10 \mathrm{M}$ and appears to be influenced by the presence and relative abundance of common carp, river carpsucker, and channel catfish. The shift in community structure of samples from group 3 to group 4 reflects changes from predominantly coldwater fishes to warmwater fishes.

Spearman rank correlation analysis was used to determine which physical and chemical variables were related to the relative abundance of fish from samples in group 3 of the cluster analysis. All group 3 sites are in the Southern Rocky Mountains physiographic province except for site 8T in the Basin and Range physiographic province; all sites in group 3 are in the Arizona/ New Mexico Plateaus ecoregion, except site 2CB in the Southern Rocky Mountains ecoregion (fig. 1). Most of the physical and chemical variables from sites in group 3 were interrelated ( $p<$ 0.05 ) and each variable was correlated to elevation. The relative abundance of brown trout, longnose dace, and Rio Grande sucker in samples from group 3 sites were related to elevation, specific conductance, and ammonia plus organic nitrogen $(p<0.05)$. The relative abundance of brown trout and longnose dace was positively correlated $(r=0.86$ and 0.88 , respectively) and Rio Grande sucker was negatively correlated $(r=-0.82)$ with elevation. This indicates that brown trout and longnose dace should be more abundant at high elevations and Rio Grande sucker should be more abundant at low elevations.

Of the three species of fish in group 3 sites that related to the selected chemical variables, the relative abundance of Rio Grande sucker had the strongest positive correlation with specific conductance $(r=0.88)$, and ammonia plus organic nitrogen $(r=0.75)$. The relative abundance of brown trout and longnose dace at group 3 sites was negatively correlated with specific conductance ( $r=-0.88$ and -0.76 , respectively), and ammonia plus organic nitrogen $(r=-0.59$ and -0.73 , respectively). This indicates that brown trout and longnose dace are less abundant and Rio Grande sucker are more abundant at sites where specific conductance and ammonia plus nitrogen is high. Furthermore, the relative abundance of the brown trout, longnose dace, and Rio 
Grande sucker, where present, can be used as an indicator of the condition of streams in the Rio Grande Basin. However, variables other than those measured, such as habitat quality, hydrologic characteristics, and water temperature can influence the distribution and relative abundance of these fish.

Differences in the physical and chemical variables at the two sites (9M and 10M) from the group 4 sites did not allow further analysis of the correlation of these variables with the relative abundance of fish for samples from these sites. The two sites were in same physiographic provinces but different ecoregions (fig. 1). Chemical variables (specific conductance, alkalinity, hardness, dissolved solids, sulfate, chloride, and ammonia plus organic nitrogen) at these sites were significantly different ( $p>0.05$ ).

During this study, 13 native and 16 introduced species of fish were identified (table 2). The trophic structure of the fish communities at sites $9 \mathrm{M}$ and $10 \mathrm{M}$ were the most diverse (table 2). The fish communities at sites $3 \mathrm{CB}$ and $7 \mathrm{~T}$ were composed of intolerant fish, and the number of tolerant fish at other sites (table 2) ranged from two (at sites $1 \mathrm{M}, 2 \mathrm{CB}$, and $5 \mathrm{M}$ ) to nine (at site 9M). In most samples, the occurrence of external anomalies was relatively low (less than 4 percent). Fish communities sampled at site $9 \mathrm{M}$, reaches $\mathrm{B}$ and $\mathrm{C}$, had the highest frequency of anomalies ( 34 and 23 percent, respectively).

\section{Spatial Pattern of Community Structure}

Fish communities at six sites sampled during 1994 were used to assess the large-scale spatial patterns in the community structure and biotic integrity (table 1). Although site 7T was sampled in 1994, data from this site were not used in this analysis because the community was composed of only two intolerant, introduced trouts (brook and rainbow). Site 10M was sampled during April and November 1994 but only the November sample was used in this analysis, because this sample was more seasonally comparable to the other samples collected during 1994. Further discussion on the large-scale spatial pattern of fish communities is limited to those sites other than sites 7T and 10M (April) where fish were sampled in 1994.

Species richness at the sites sampled in 1994 reveals little information pertaining to the diversity and biotic integrity of the fish communities. Most sites had either six (sites $1 \mathrm{M}$ and $2 \mathrm{CB}$ ) or seven $(5 \mathrm{M}, 6 \mathrm{~T}$, and $9 \mathrm{M})$ species; the most species collected at any given site was 10 (site $10 \mathrm{M}$, November sample).

The percentages of introduced species, omnivores, tolerant individuals, and anomalies reveal more information about the structure of fish communities and potential environmental stress to these communities in 1994. Introduced fish species were dominant at sites $1 \mathrm{M}, 2 \mathrm{CB}, 5 \mathrm{M}$, and 9M; native species dominated sites 6T and 10M (November sample) (fig. 6). The relative abundances of brown trout and white sucker at site $1 \mathrm{M}$ (34 and 28 percent, respectively) were similar to those at site $3 \mathrm{CB}$ ( 31 and 27 percent, respectively). At site $5 \mathrm{M}$, white sucker was the dominant species with a relative abundance of 56 percent; brown trout, however, composed less than 5 percent of the fish community. Introduced channel catfish, common carp, and white sucker with relative abundances of 31,17 , and 25 percent, respectively, were the dominant species at site $9 \mathrm{M}$. The relative percentages of introduced species at sites $1 \mathrm{M}, 2 \mathrm{CB}, 5 \mathrm{M}$, and $9 \mathrm{M}$ are indicative of biological stress on the communities at these sites. The native Rio Grande chub was the dominant species at site $6 \mathrm{~T}$ and composed 37 percent of the fish community. At site $10 \mathrm{M}$ (November sample), the native gizzard shad was the dominant species with a relative abundance of 55 percent. 


\section{EXPLANATION}

- san luis closed basin boundary

$1 M-$ FISH COMMUNITY SAMPLE SITE AND NUMBER--Identifier refers to table $\mathrm{i}$

PERCENTAGE OF INTRODUCED AND NATIVE FISH IN SAMPLES COLLECTED DURING 1994

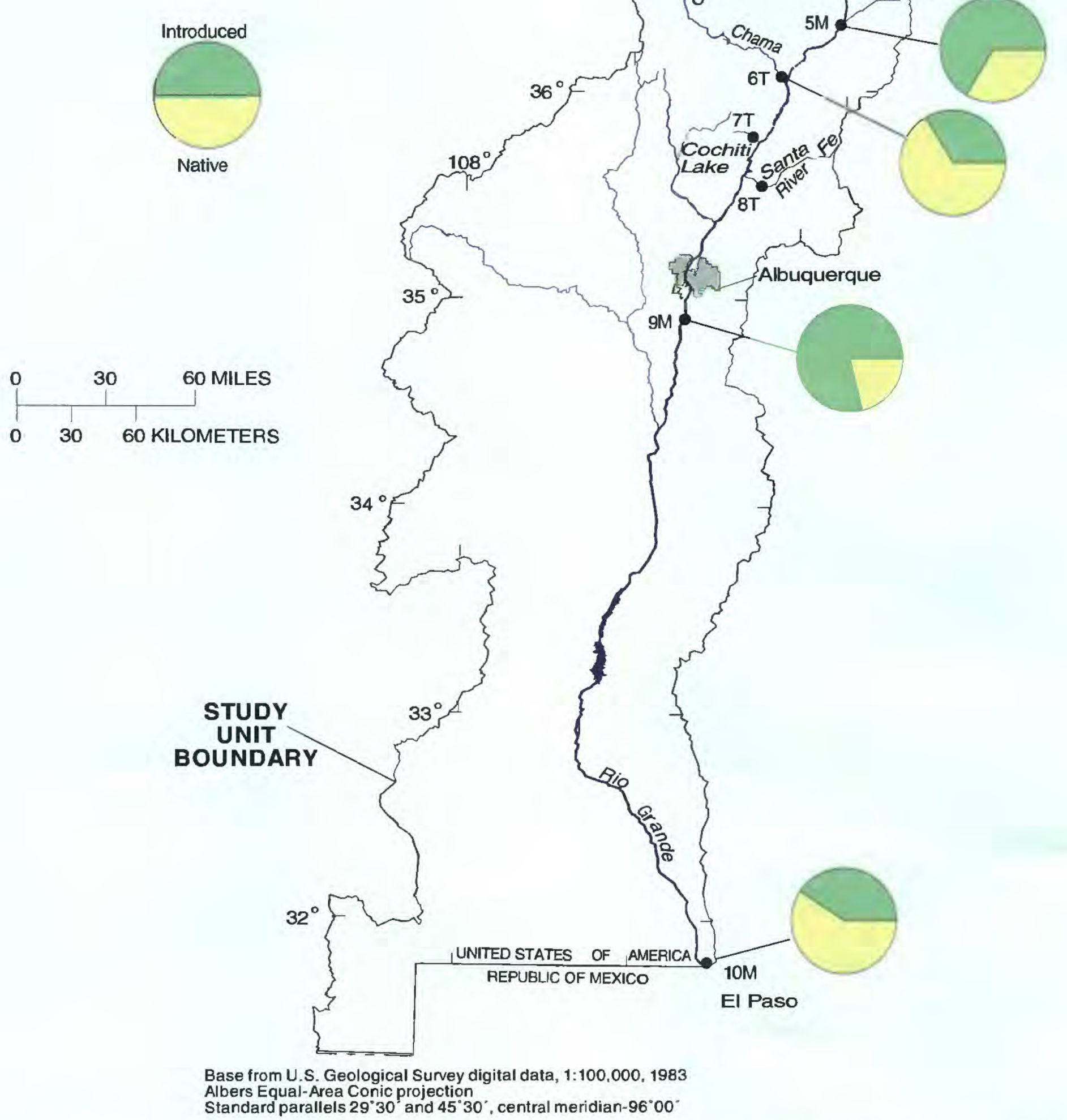

Figure 6.--Percentage of native and introduced fish from samples collected in 1994. 
Omnivores were the dominant trophic group of the fish communities at sites $5 \mathrm{M}, 6 \mathrm{~T}, 9 \mathrm{M}$, and $10 \mathrm{M}$ (November sample), ranging from 62 percent at site $9 \mathrm{M}$ to 84 percent at site $5 \mathrm{M}$ (fig. 7 ). The dominance of omnivores is an indication of potential physicochemical habitat degradation at these sites. Insectivores were identified at each site during 1994 and were the dominant trophic group at sites in Colorado (fig. 7). At sites $1 \mathrm{M}$ and $2 \mathrm{CB}$, insectivores account for 71 and 69 percent, respectively, of the overall community structure. The complexity of the community structure generally increased at sites $9 \mathrm{M}$ and $10 \mathrm{M}$ where generalists and predators composed more than 15 percent of the community.

The relative abundances of tolerant fish species in the community structure at sites sampled in 1994 varied among sites (fig. 8). The fish communities at sites $1 \mathrm{M}, 2 \mathrm{CB}$, and $10 \mathrm{M}$ (November sample) are dominated by intolerant species, composing 71, 70, and 82 percent, respectively, of the community structure. The predominant intolerant species at sites $1 \mathrm{M}$ and $2 \mathrm{CB}$ are brown trout and longnose dace and at site $10 \mathrm{M}$ (November sample) are gizzard shad, sunfishes, and white bass. At sites $5 \mathrm{M}$ and $6 \mathrm{~T}$ tolerant species composed 62 and 55 percent, respectively, of the community structure; white sucker was the predominant tolerant species at both sites. Tolerant species account for the entire fish community at site $9 \mathrm{M}$ in 1994, suggesting potential chemical or physical perturbations at this site.

During 1994, in all samples the occurrence of anomalies was less than 2 percent of the individuals, with the exception of the sample from site 9M. Anomalies were observed in 14 percent of the fish from site $9 \mathrm{M}$, further suggesting chemical or physical perturbation at this site.

Fish communities from three reaches at sites $8 \mathrm{~T}$ and $9 \mathrm{M}$ were sampled in 1995 to assess small-scale spatial patterns in the structure of fish communities (fig. 9). At site $8 \mathrm{~T}$ the fish community at reach $C$ appears to differ from those at reaches $A$ and $B$; species richness and total number of individuals at reach $C$ was greater than at the other reaches. Rio Grande sucker was the predominant species at each reach at site $8 \mathrm{~T}$ (fig. 9). The relative abundance of Rio Grande sucker was 95 and 94 percent of the community at reaches $A$ and $B$, respectively. At reach $C$, the decrease in the relative abundance of Rio Grande sucker (57 percent) corresponds with the increase in the relative abundance of fathead minnow ( 40 percent). The increase in the relative abundance of fathead minnow can be attributed to sampling in shallow pools which were only noted in reach $\mathrm{C}$, and these pools provided an important habitat for a large number of fathead minnow. No correlation was significant between physical variables (channel width, depth, and substrate) or chemical variables (water temperature, dissolved oxygen, and specific conductance) between reaches at sites $8 \mathrm{~T}$. The spatial pattern of fish communities at site $8 \mathrm{~T}$ might be associated with natural variability or it could be associated with the presences of habitat features such as pools.

At site $9 \mathrm{M}$, the fish community at reach $\mathrm{C}$ appears to slightly differ from those at reaches $\mathrm{A}$ and B (fig. 9). At reach A, common carp, white sucker, and channel catfish had similar relative abundances (32, 23, and 31 percent, respectively) and at reach B, both common carp and white sucker had a relative abundance of 22 percent and channel catfish had a relative abundance of 41 percent. At reach $C$, the increased relative abundance of common carp (53 percent) appears to correspond with the decreased relative abundances of white sucker and channel catfish (12 and 24 percent). No correlation was significant between physical variables (channel width, depth, and substrate) and chemical variables (water temperature, dissolved oxygen, and specific conductance) between reaches at sites $9 \mathrm{M}$. The spatial pattern of fish communities at site $9 \mathrm{M}$ could be attributed to natural variability of the fish communities. 


\section{EXPLANATION}

- San luis closed basin boundary

$1 \mathrm{M}$

FISH COMMUNITY SAMPLE SITE AND NUMBER--Identifier refers to table 1

PERCENTAGE OF TROPHIC GROUPS OF FISH IN SAMPLES COLLECTED DURING 1994

Insectivores

Herbivores

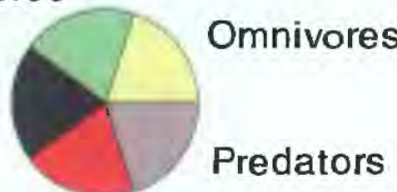

Generalists

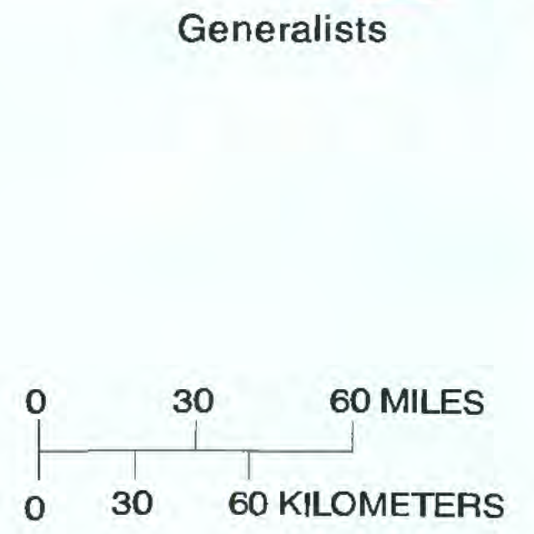

OMETERS
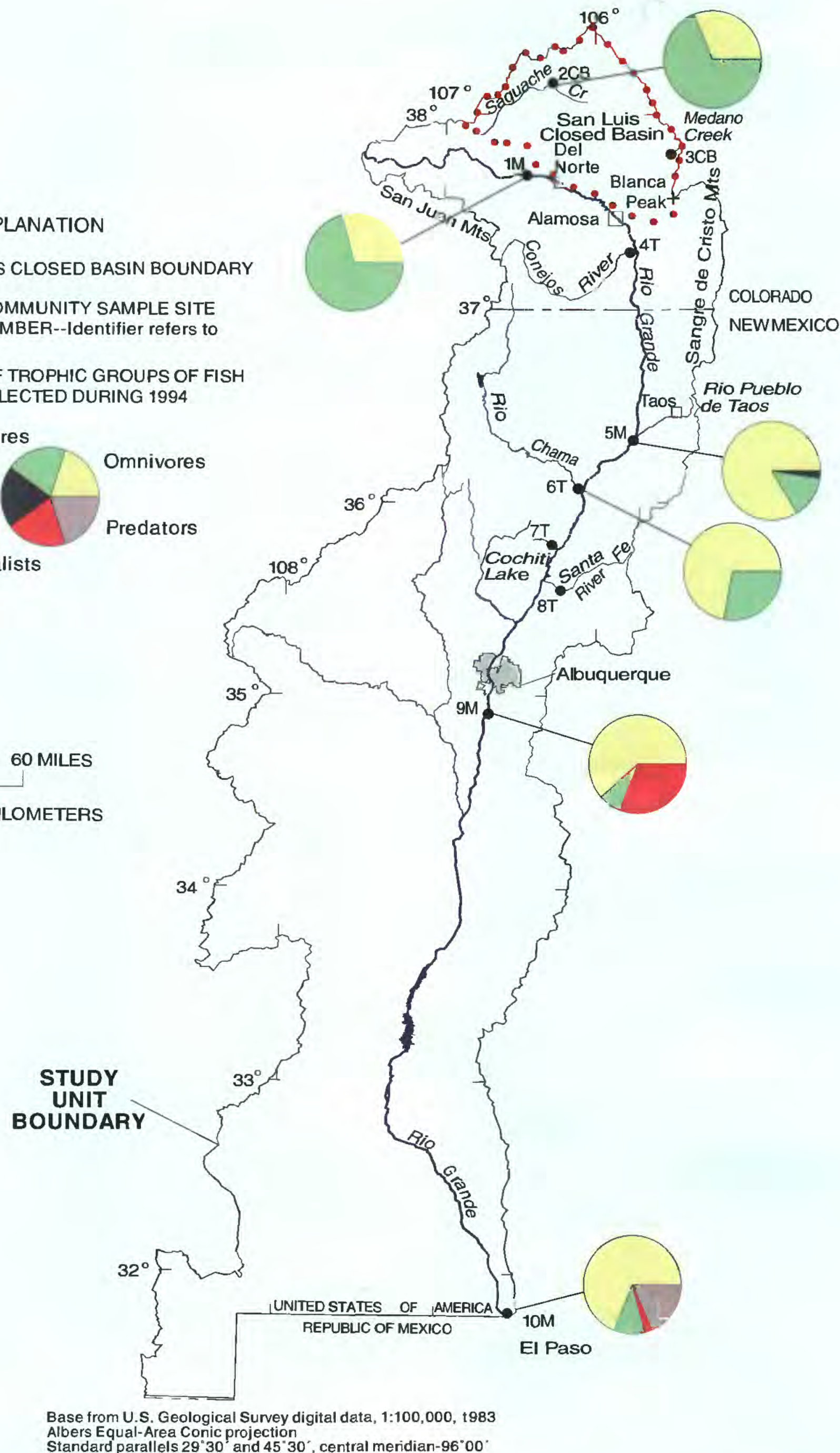

Figure 7.--Percentage of trophic groups of fish from samples collected in 1994. 


\section{EXPLANATION}

- san luis closed basin boundary

1M FISH COMMUNITY SAMPLE SITE AND NUMBER--Identifier refers to table 1

PERCENTAGE OF TOLERANT AND INTOLERANT FISH IN SAMPLES COLLECTED DURING 1994

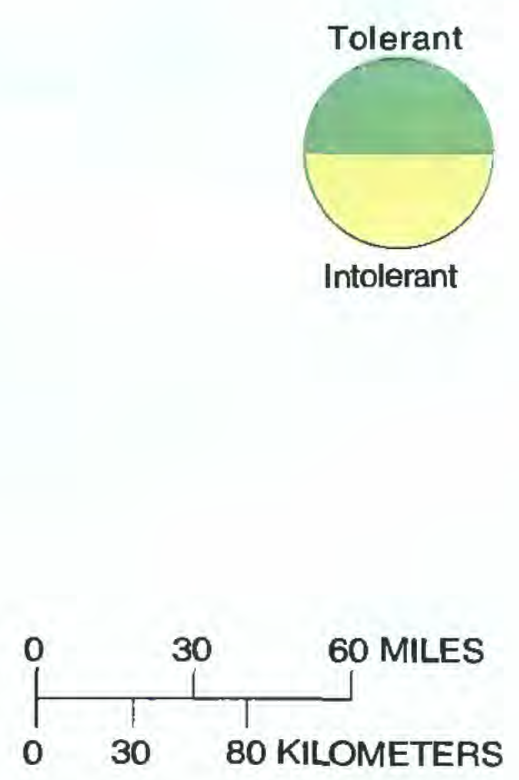

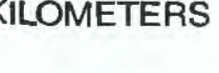

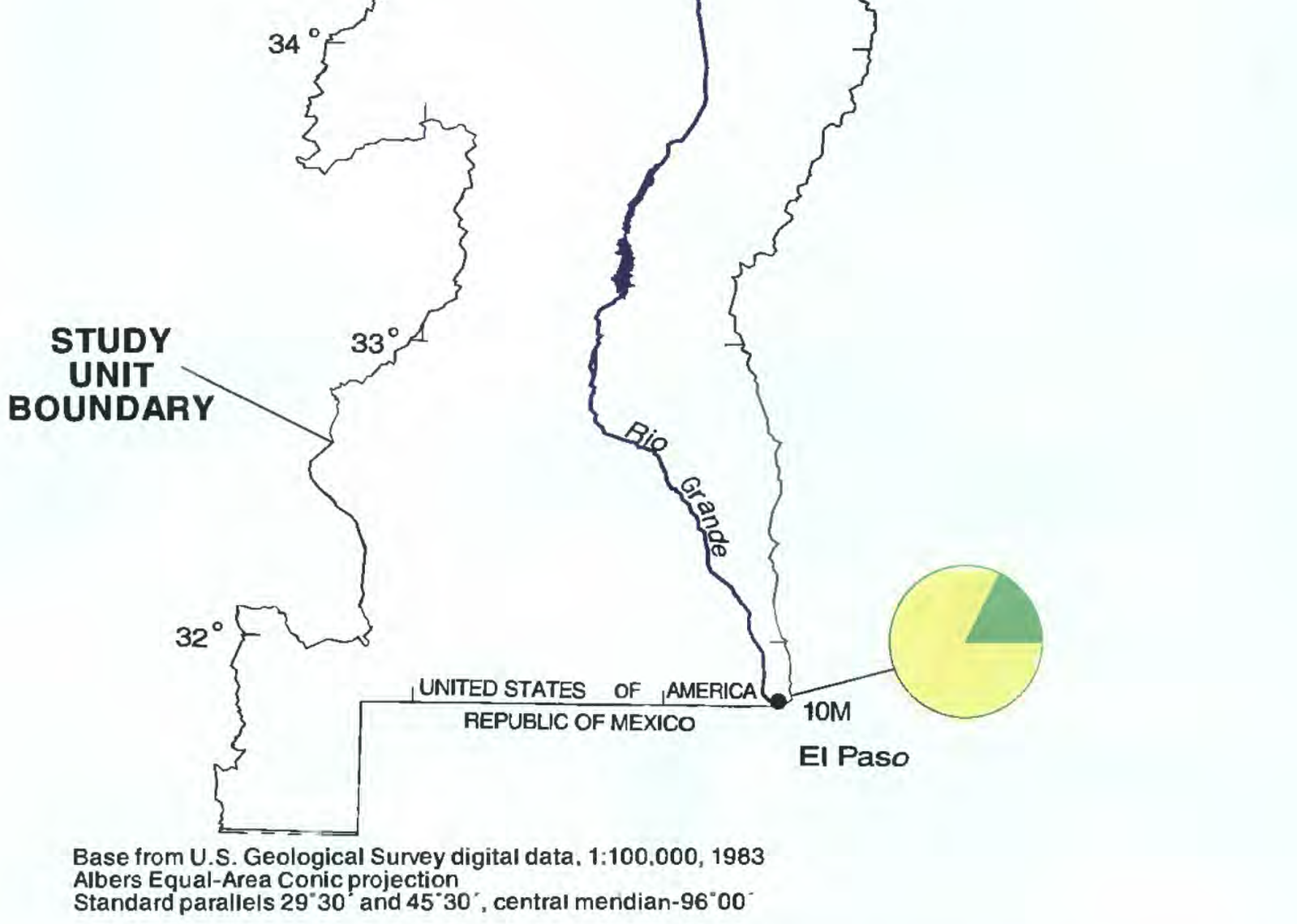

Figure 8.--Percentage of tolerant and intolerant fish from samples collected in 1994. 


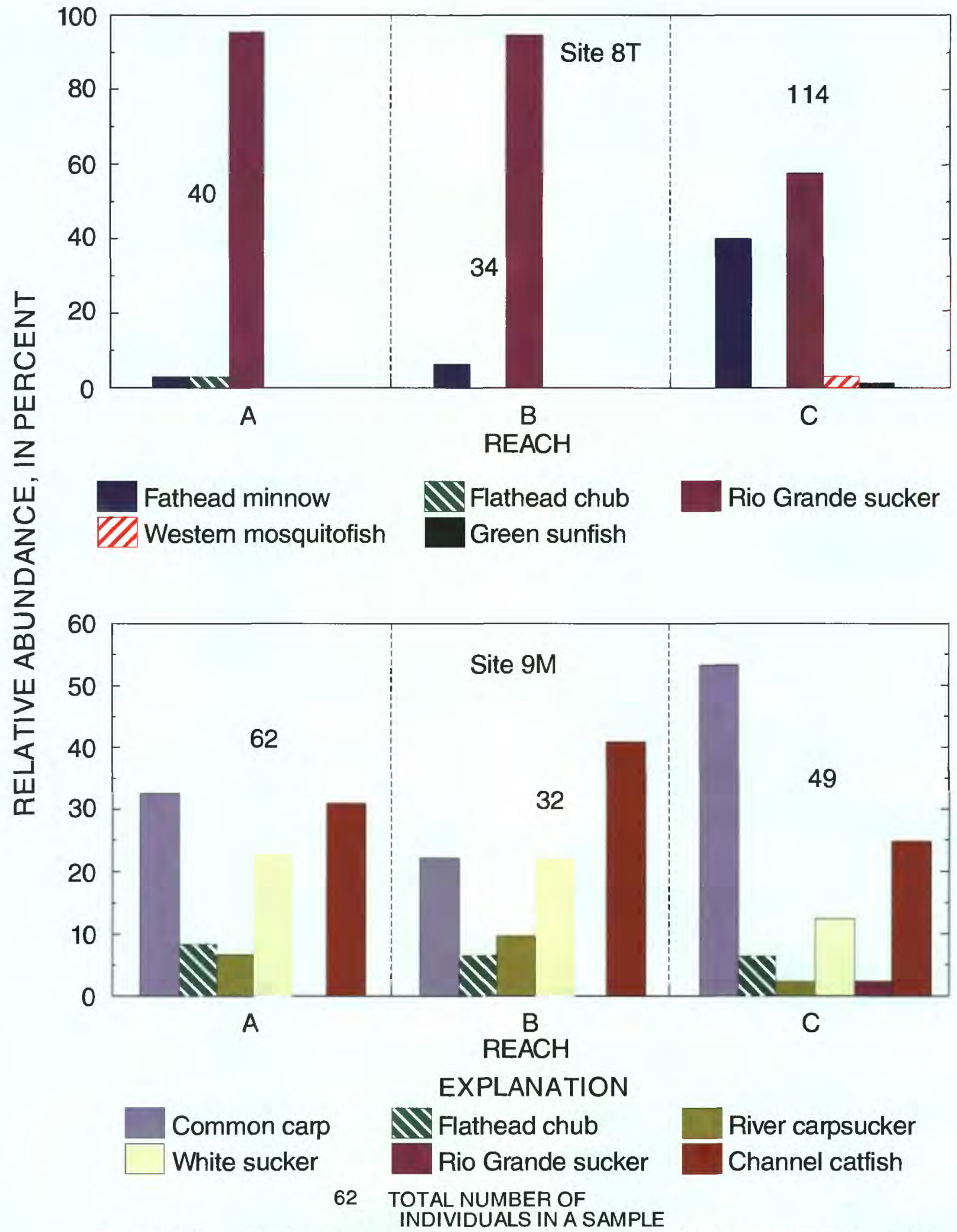

Figure 9.--Relative abundance and total number of individual fish in samples collected from three reaches at sites 8T and 9M in 1995. 


\section{Temporal Pattern of Community Structure}

Although three years of fish community data may not be adequate to establish a trend, the temporal pattern of community structure at sites $1 \mathrm{M}, 2 \mathrm{CB}, 7 \mathrm{~T}$, and $9 \mathrm{M}$ (reach B) could be influenced by variables such as sampling efficiency, water chemistry, and stream discharge. The variability associated with sampling efficiency was minimized by using the same types of collection equipment, backpack, barge, or raft electrofishing units at a given site each year. Chemical variables (specific conductance, alkalinity, hardness, dissolved solids, sulfate, chloride, and ammonia plus organic nitrogen) at these sites were not significantly different ( $p>$ 0.05). Temporal changes in water chemistry as measured by these chemical variables do not appear to have an influence on the temporal pattern of community structure during the 3 years of sampling at these sites. Variability in stream discharge, as seen in the timing and duration of peak flow events, appears to be an important environmental factor influencing fish communities.

The temporal decline in the total number of individuals at sites $1 \mathrm{M}, 2 \mathrm{CB}, 7 \mathrm{~T}$, and $9 \mathrm{M}$ (reach B) might be associated with natural variability within the fish communities or it might be attributed to the variability of in stream discharge at these sites. Mean daily discharge at sites $1 \mathrm{M}, 2 \mathrm{CB}$, and $7 \mathrm{~T}$ were compared to the interquartile range of the mean daily discharge for the period of record for each site (fig. 10). Because of a lack of mean daily discharge at site 9M, data from the USGS gaging station Rio Grande at Albuquerque, New Mexico, were used to estimate the mean daily discharge and the interquartile range for the period of record at this site (fig. 10). Each of the four sites, with the exception of site 1M, samples had a temporal decline in total number of individuals (fig. 11). At site $1 \mathrm{M}$ in 1994, the total number of individuals was largest when compared to the other years of sampling at the site.

At site $1 \mathrm{M}$ in 1995, the total number of individuals was about 84 percent less of the number of individuals in 1994. The reduction in the total number of individuals in the sample from site $1 \mathrm{M}$ in 1995 might be a result of an environmental disturbance associated with stream discharge; the mean daily discharge at the site immediately prior to the time of sampling in 1995 exceeded the interquartile range for the period of record for the site (fig. 10).

In 1993 at site $2 \mathrm{CB}$, the mean daily discharge prior to the time of sampling was within the interquartile range for the period of record for the site, but in 1994 a peak flow event occurred shortly prior to the time of sampling, and in 1995 a peak flow event occurred about the time of sampling and mean daily discharge exceeded the interquartile range for the period of record for approximately 3 months prior to the time of sampling (fig. 10). In 1995, the total number of individuals was about 86 percent of the number of individuals in 1994 and about 80 percent of the number of individuals in 1993.

Mean daily discharge was not available near the time of sampling at site 7T in 1993; the mean daily discharge prior to the time of sampling was within the interquartile range for the period of record in 1994. However at site 7T in 1995, a peak flow event occurred shortly before the time of sampling and mean daily discharge exceeded the interquartile range for the period of record during two periods within the two months prior to sampling (fig. 10). In 1995, the total number of individuals was about 83 percent of the number of individuals in 1994.

At site 9M (reach B) in 1993 and 1994 the estimated mean daily discharge at site 9M (reach B) was within the estimated interquartile range for the period of record with a few exceptions; however in 1995 the mean daily discharge exceeded the estimated interquartile range for an extended period prior to sampling (fig. 10). In 1995, the total number of individuals was about 71 percent of the number of individuals in 1994 and about 38 percent of the number of individuals in 1993. 

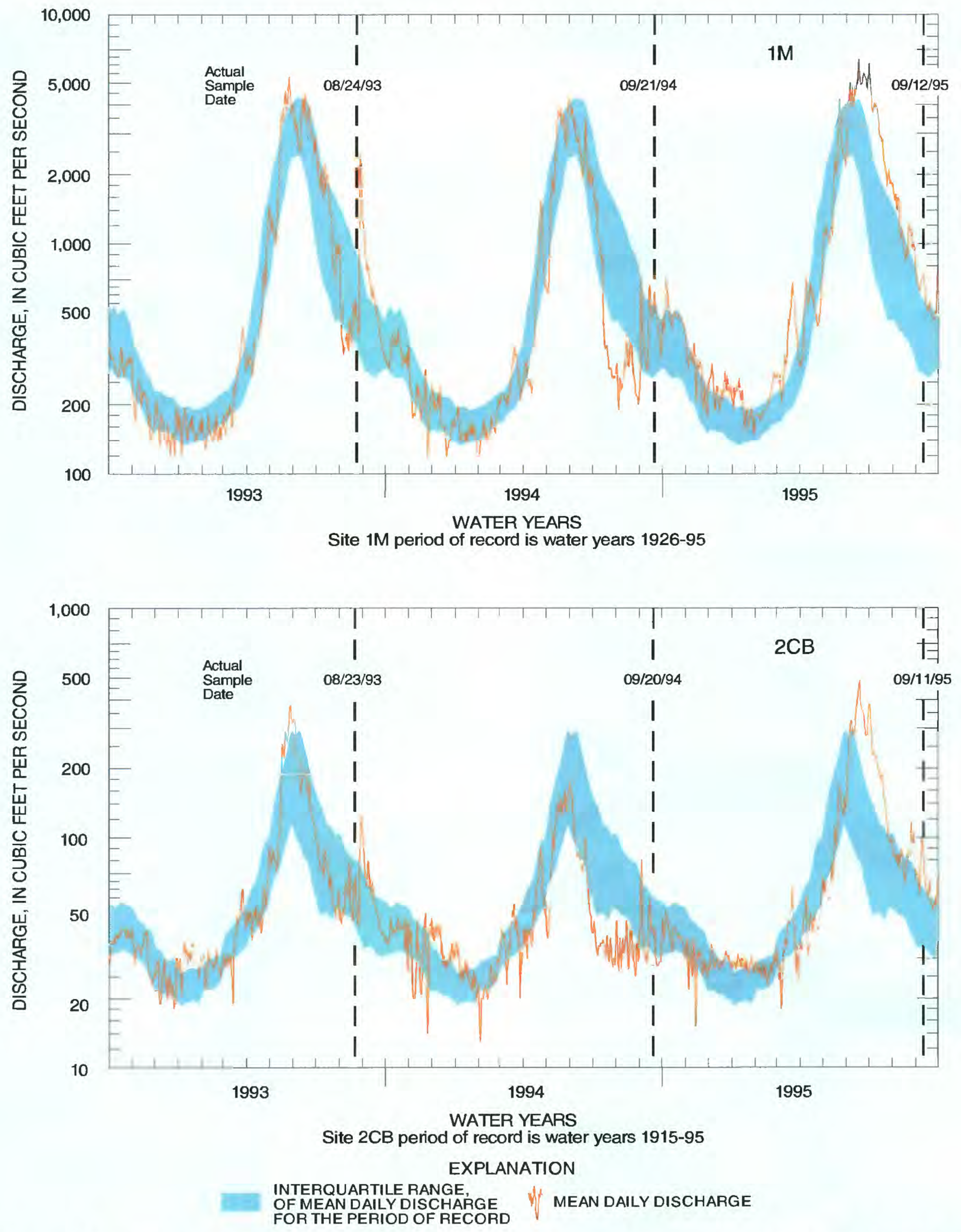

Figure 10.--Mean daily discharge and interquartile range of mean daily discharge for period of record at selected sites in the Rio Grande Basin, 1993-95. 


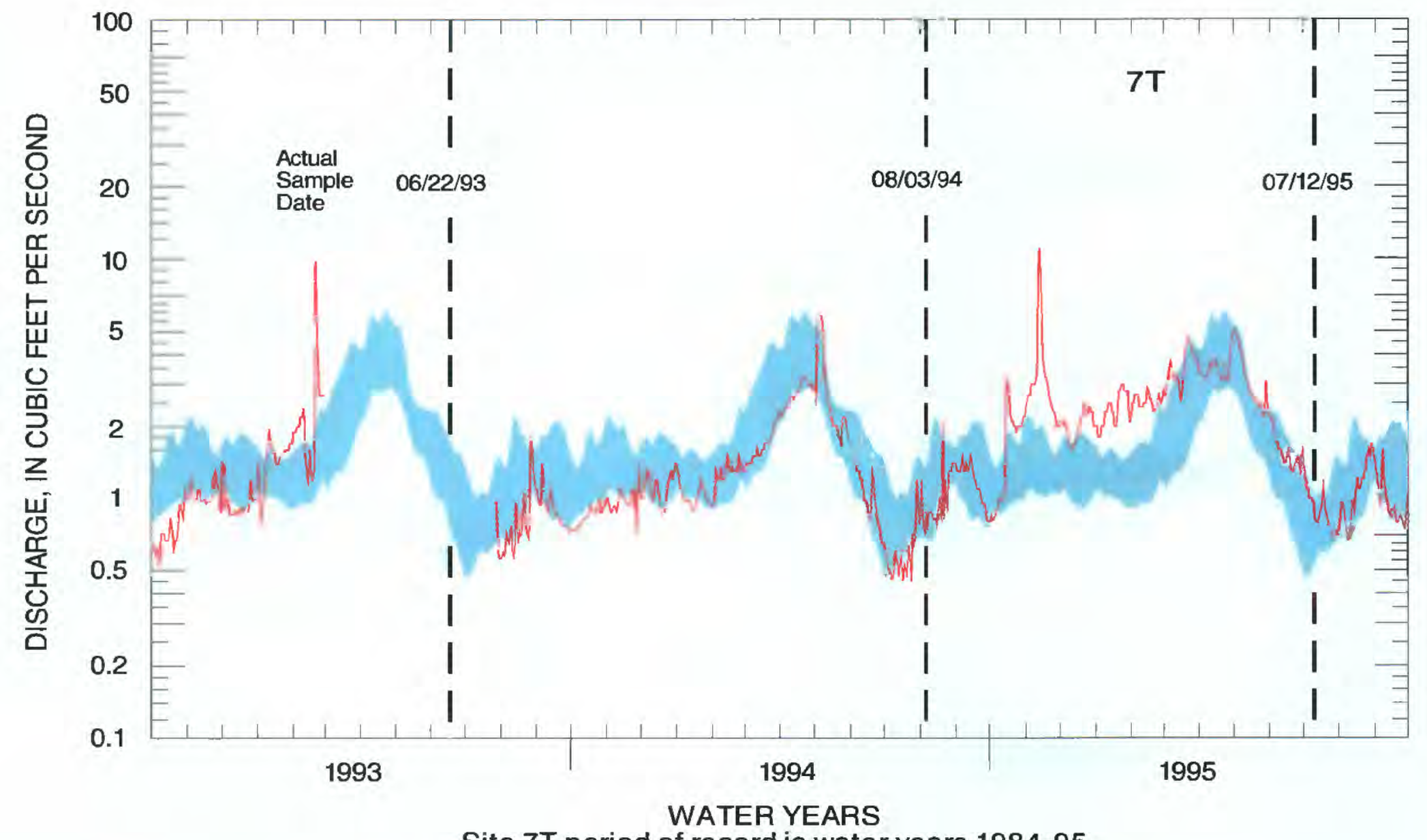

Site 7T period of record is water years 1984-95

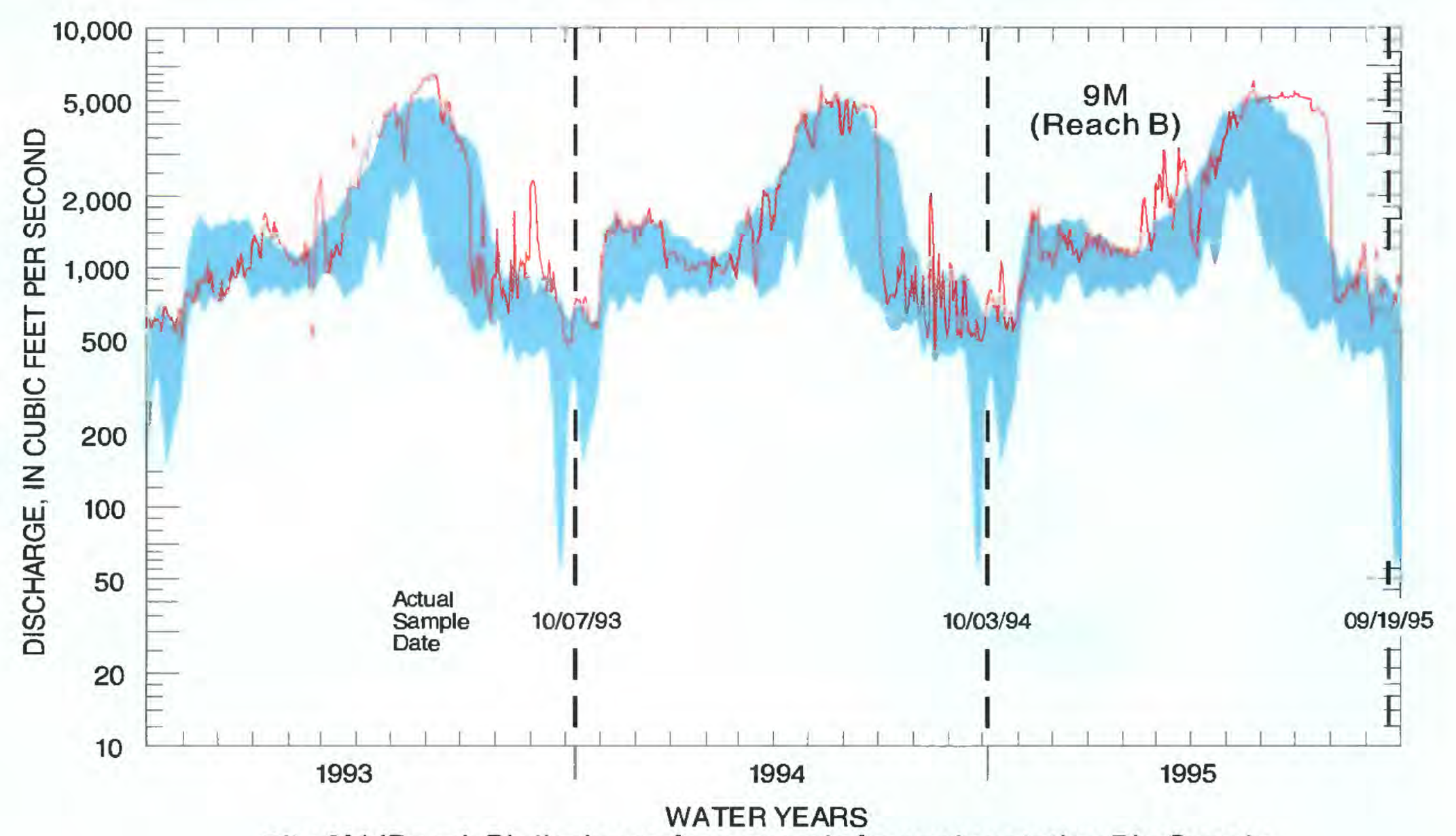

Site $9 \mathrm{M}$ (Reach $B$ ) discharge from records for gaging station Rio Grande at Albuquerque in period of record water years 1974-1995

EXPLANATION

INTERQUARTILE RANGE

OF MEAN DAILY DISCHARGE

FOR THE PERIOD OF RECORD

Wh MIf MEAN DAILY DISCHARGE

Figure 10.--Mean daily discharge and interquartile range of mean daily discharge for period of record at selected sites in the Rio Grande Basin, 1993-95--Concluded. 


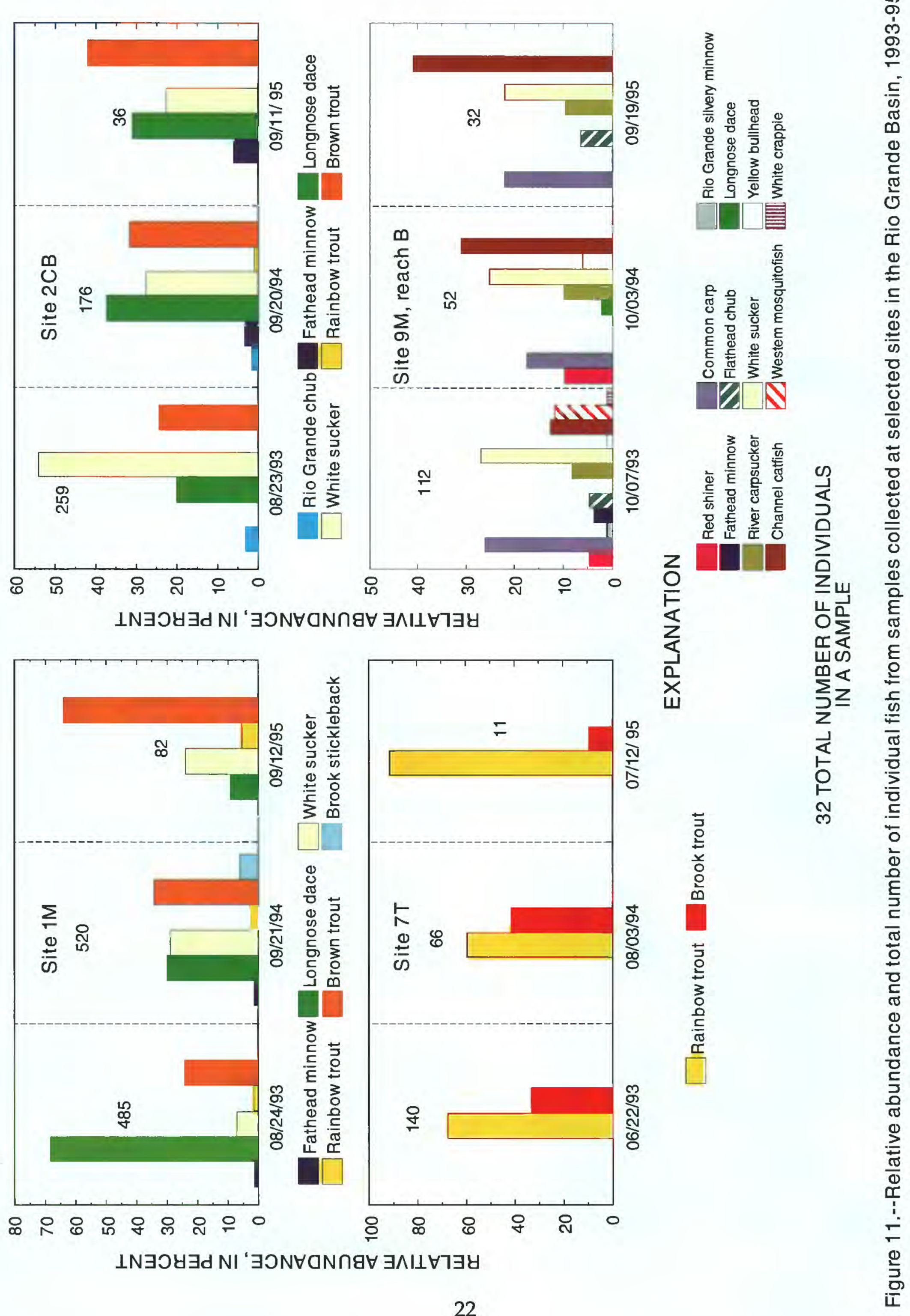



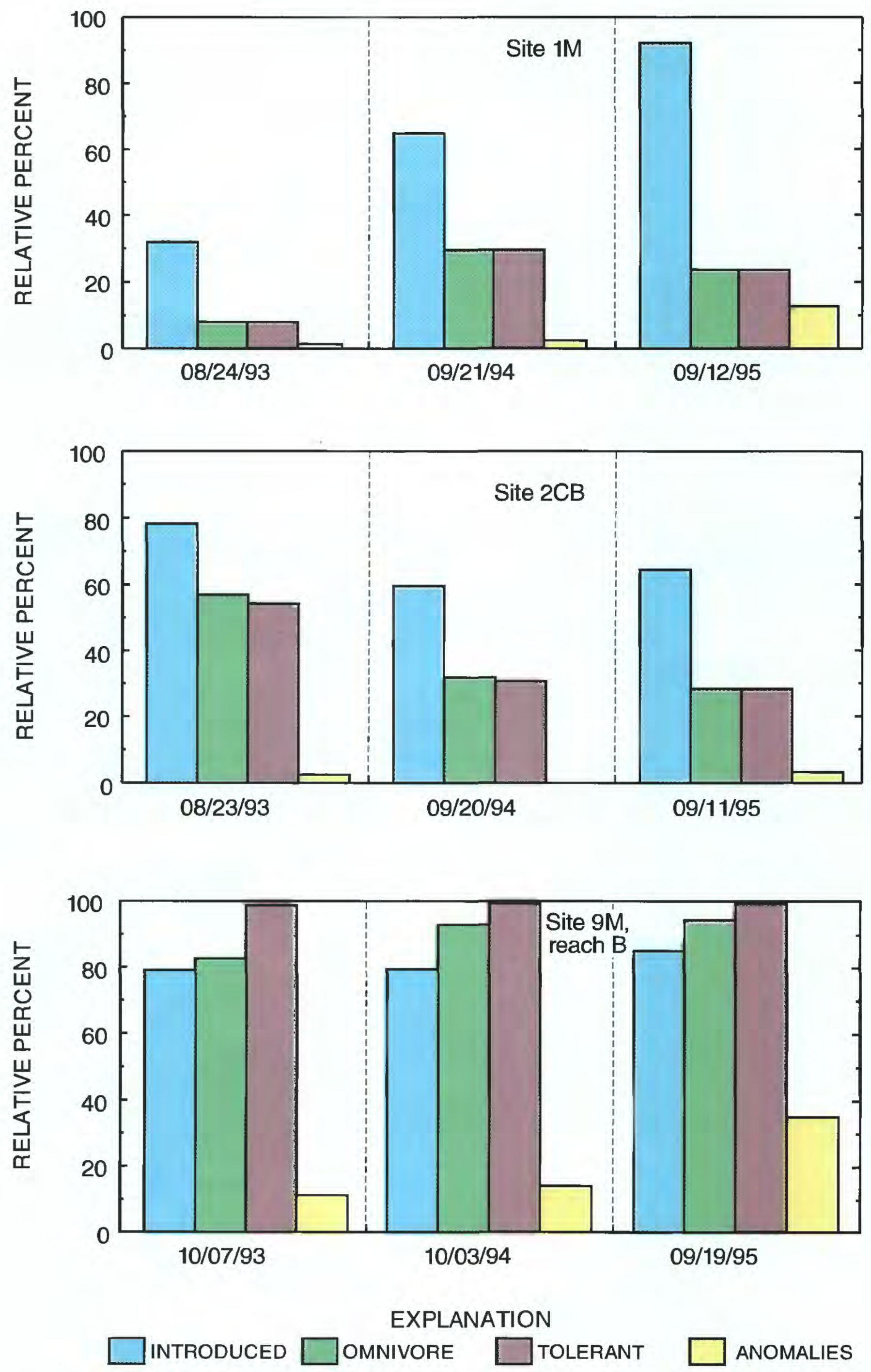

Figure 12.--Indicators of the biotic integrity of fish communities at selected sites in the Rio Grande Basin, 1993-95. 
The relative abundance and total number of individuals in a sample varied during the 3 years of sampling at sites $1 \mathrm{M}, 2 \mathrm{CB}, 7 \mathrm{~T}$, and $9 \mathrm{M}$ (reach B) (fig. 11). The community structure of samples at a site showed temporal variability in either the relative abundance of individual fish, the dominant fish species, or both. The relation between relative abundance and the biotic integrity was variable among samples from sites $1 \mathrm{M}, 2 \mathrm{CB}, 7 \mathrm{~T}$, and $9 \mathrm{M}$.

The biotic integrity at site $1 \mathrm{M}$ appears more degraded in 1995 than in previous years (fig. 12). The percentage of introduced species at site $1 \mathrm{M}$ increased from 31 percent in 1993 to 92 percent in 1995 and the percentage of anomalies increased from less than 2 percent in 1993 and 1994 to 12 percent in 1995.

At site $2 \mathrm{CB}$, the relative abundance of white sucker and the total number of individuals temporally declined (fig. 11), but the biotic integrity was relatively unchanged with respect to the relative percentage of introduced species, omnivores, tolerant fish, or anomalies (fig. 12). The temporal decline in the relative abundance of white sucker might be attributed to the sampling of a backwater area only in 1993. This backwater area provided a habitat for a large number of juvenile white suckers.

At site 7T, rainbow trout was the dominant species but the total number of individuals temporally declined (fig. 11). The small number of total individual at site 7T in 1995 might be an influence on the difference in relative abundance of rainbow trout when compared to the previous years.

At site 9M (reach B) species richness was greatest in the sample collected in 1993 (fig. 11). The total number of red shiner, Rio Grande silvery minnow, fathead minnow, flathead chub, and western mosquitofish was small at site 9M (reach B) in 1993, but their combined relative abundances composed about 21 percent of the community (fig. 11). During the following year of sampling at site $9 \mathrm{M}$ (reach B), many of these fish were absent and their combined contribution to the community was about 10 percent. The relative abundances of larger fish, such as common carp, white sucker, and channel catfish, composed about 80 percent of the community at site $9 \mathrm{M}$ (reach B) in 1994 and 1995. Backwater areas were present at site 9M (reach B) only in 1993 and this habitat appears to be critical for the red shiner, Rio Grande silvery minnow, fathead minnow, flathead chub, and western mosquitofish, which were collected primarily during 1993.

The fish community at site $9 \mathrm{M}$ (reach B) appears to show the most signs of environmental stress, because each sample from the site was predominantly omnivorous, introduced fish, and all except 2 percent of the fish sampled in 1993 were tolerant individuals (fig. 12). In addition, the occurrence of anomalies was about 2.5 times more frequent in the 1995 sample from $9 \mathrm{M}$ than in samples from the previous 2 years (fig. 12). 


\section{SUMMARY}

Physical, chemical, and fish community data from stream reaches influenced by natural and anthropogenic factors allow for an integrated approach to characterizing surface-water quality within the Rio Grande Valley study unit. Fish communities were sampled at 10 sites in the study unit from June 1993 through September 1995. The influence of a stream's physical and chemical characteristics on the fish community was determined through regression, correlation, and multivariate statistical analysis and four broadly applicable metrics of biotic integrity (percentages of introduced individuals, omnivores, tolerant individuals, and anomalies).

Twenty-nine species of fish representing 10 families were identified in 25 samples collected during this study. Species richness ranged from 1 to 13 . Species richness increased with increasing contributing drainage area.

Cluster analysis of the 25 samples collected during this study delineated four groups of sites that were based on the similarity of the fish communities. The first two groups were individual sites with low species richness. The third group contained the most samples, and the forth group consisted of samples from sites $9 \mathrm{M}$ and $10 \mathrm{M}$. The shift in community structure of samples from group 3 to group 4 reflects changes from predominantly coldwater fishes to warmwater fishes.

Spearman rank correlation analysis was used to determine which physical and chemical variables were related to the relative abundance of fish from samples in group 3 of the cluster analysis. The relative abundance of brown trout and longnose dace had a positive correlation with elevation and a negative correlation with specific conductance and ammonia plus organic nitrogen. Rio Grande sucker had a negative correlation with elevation and a positive correlation with specific conductance and ammonia plus organic nitrogen. These data suggest that the relative abundance of the brown trout, longnose dace, and Rio Grande sucker, where present, can be used as an indicator of the condition of streams in the Rio Grande Basin. However, variables other than those measured, such as habitat quality, hydrologic characteristics, and water temperature can influence the distribution and relative abundance of these fish.

Four metrics of biotic integrity (percentages of introduced individuals, omnivores, tolerant individuals, and anomalies) were used in this study to provide a broad overview of the community structure. Fish communities at six sites sampled during 1994 were used to assess the large-scale spatial patterns in the community structure and biotic integrity. The percentages of introduced species, omnivores, tolerant individuals, and anomalies reveal more information about the structure of fish communities and potential environmental stress to these communities in 1994. Introduced fish species were dominant at sites 1M, 2CB, 5M, and 9M; native species dominated sites $6 \mathrm{~T}$ and $10 \mathrm{M}$ (November sample). The relative percentages of introduced species at sites $1 \mathrm{M}, 2 \mathrm{CB}, 5 \mathrm{M}$, and $9 \mathrm{M}$ are indicative of biological stress on the communities at these sites.

The fish communities at sites $1 \mathrm{M}, 2 \mathrm{CB}$, and $10 \mathrm{M}$ (November sample) are dominated by intolerant species. The predominant intolerant species at sites $1 \mathrm{M}$ and $2 \mathrm{CB}$ are brown trout and longnose dace and at site $10 \mathrm{M}$ (November sample) are gizzard shad, sunfishes, and white bass. At sites $5 \mathrm{M}$ and $6 \mathrm{~T}$, the fish community was primarily tolerant species; white sucker was the predominant tolerant species at both sites. Tolerant species account for the entire fish community at site 9M in 1994, suggesting environmental stress at this site. 
During 1994, in all samples the occurrence of anomalies was less than 2 percent of the individuals, with the exception of the sample from site $9 \mathrm{M}$. Anomalies were observed in 14 percent of the fish from site $9 \mathrm{M}$, further suggesting chemical perturbation at this site.

Fish communities from three reaches at sites $8 \mathrm{~T}$ and $9 \mathrm{M}$ were sampled in 1995 to assess small-scale spatial patterns in the structure of fish communities. The spatial pattern of fish communities at site $8 \mathrm{~T}$ might be associated with natural variability or it could be associated with the presences of habitat features such as pools. The spatial pattern of fish communities at site $9 \mathrm{M}$ might be attributed to natural variability of the fish communities.

Although three years of fish community data may not be adequate to establish a trend, variability in stream discharge, as seen in the timing and duration of peak flow events, appears to be an important environmental factor influencing fish communities. Fluctuations in stream discharge may account for differences between the total number of individuals in samples collected during the three years of sampling at sites $1 \mathrm{M}, 2 \mathrm{CB}, 7 \mathrm{~T}$, and $9 \mathrm{M}$ (reach B). All sites, with the exception of site $1 \mathrm{M}$, had a decline in total number of individuals in a sample. The temporal decline in the total number of individuals at these site might also be associated with the natural variability within the fish communities.

The relative abundance and total number of individuals in a sample varied during the 3 years of sampling at sites $1 \mathrm{M}, 2 \mathrm{CB}, 7 \mathrm{~T}$, and $9 \mathrm{M}$ (reach B). The community structure of samples at a site showed temporal variability in either the relative abundance of individual fish, the dominant fish species, or both. The fish community at site $9 \mathrm{M}$ (reach B) appears to show the most signs of environmental stress, because each sample from the site was predominantly omnivorous, introduced fish, and all except 2 percent of the fish sampled in 1993 were tolerant individuals. In addition, the occurrence of anomalies was about 2.5 times more frequent in the 1995 sample from $9 \mathrm{M}$ than in samples from the previous 2 years.

\section{REFERENCES CITED}

Blanchard, P.J., 1993, Ground-water-level fluctuations in the Cochiti Dam-Peña Blanca area, Sandoval County, New Mexico, 1976-89: U.S. Geological Survey Water-Resource Investigations Report 92-4193, 72 p.

Bramblett, R.G., and Fausch, K.D., 1991, Variable fish communities and the index of biotic integrity in a western Great Plains river: Transactions of the American Fisheries Society, v. 120, p. $752-769$.

Ellis, S.R., Levings, G.W., Carter, L.F., Richey, S.F., and Radell, M.J., 1993, Rio Grande Valley, Colorado, New Mexico, and Texas: American Water Resources Association, Water Resources Bulletin, v. 29, no. 4, p. 617-646.

Fenneman, N.M., 1946, Physical divisions of the United States: U.S. Geological Survey, special map, scale 1:7,000,000.

Gammon, J.R., 1980, The use of community parameters derived from electrofishing catches of river fish as indicators of environmental quality, in Seminar on water quality management tradeoffs: U.S. Environmental Protection Agency, EPA-905/9-80-009, Washington, D.C.

Gilliom, R.J., Alley, W.M., and Gurtz, M.E., 1995, Design of the National Water-Quality Assessment Program--Occurrence and distribution of water-quality conditions: U.S. Geological Survey Circular 1112, 33 p. 


\section{REFERENCES CITED--Concluded}

Goldstein, R.M., 1981, Longitudinal succession in impact assessment of river system fish communities: American Water Resources Association Water Resources Bulletin, v. 17, p. 7581.

Hill, M.O., 1979, TWINSPAN--A FORTRAN program for arranging multivariate data in an ordered two-way table by classification of the individuals and attributes: Microcomputer Power, Ithaca, N.Y., 60 p.

Karr, J.R., 1981, Assessment of biotic integrity using fish communities: Fisheries, v. 6, p. 21-27.

Karr, J.R., and Dudley, D.R., 1981, Ecological perspective on water quality goals: Environmental Management, v. 5, p. 44-68.

Karr, J.R., Fausch, K.D., Angermeier, P.L., Yant, P.R., and Schlosser, I.J., 1986, Assessing biological integrity in running waters--A method and its rationale: Illinois Natural History Survey Special Publication Number 5, 28 p.

Meador, M.R., Cuffney, T.F., and Gurtz, M.E., 1993, Methods for sampling fish communities as a part of the National Water-Quality Assessment Program: U.S. Geological Survey Open-File Report 93-104, 40 p.

Moyle, P.B., 1994, Biodiversity, biomonitoring, and the structure of stream fish communities, in Loeb, S.L., and Spacie, A., eds., Biological monitoring of aquatic systems: Boca Raton, Fla., Lewis Publishers, $381 \mathrm{p}$.

Omernik, J.M., 1987, Ecoregions of the conterminous United States: Annals of the Association of American Geographers, v. 77, p. 118-125.

Plafkin, J.L., Barbour, M.T., Porter, K.D., Gross, S.K., and Hughes, R.M., 1989, Rapid bioassessment protocols for use in streams and rivers--Benthic macroinvertebrates and fish: U.S. Environmental Protection Agency, EPA/440/4-89/001.

Platania, S.P., 1991, Fishes of the Rio Chama and upper Rio Grande, New Mexico, with preliminary comments on their longitudinal distribution: Southwestern Naturalist, v. 36, p. 186-193.

Shelton, A.L., 1968, Species diversity and longitudinal succession of fishes: Ecology, v. 49, p. 193198.

Sublette, J.E., Hatch, M.D., and Sublette, Mary, 1990, The fishes of New Mexico: Albuquerque, N. Mex., University of New Mexico Press, 393 p.

Vannote, R.L., Minshall, G.W., Cummins, K.W., Sedell, J.R., and Cushing, C.E., 1980, The river continuum concept: Canadian Journal of Fisheries and Aquatic Science, v. 37, p. 370-377.

Ward, J.V., and Stanford, J.A., 1983, The serial discontinuity concept of lotic ecosystems, in Fontaine III, T.D., and Bartell, S.M., eds., Dynamics of lotic ecosystems: Ann Arbor, Mich., Ann Arbor Publishers, $494 \mathrm{p}$.

Woodling, John, 1985, Colorado's little fishes--A guide to the minnows and other lesser known fishes in the State of Colorado: Colorado Division of Wildlife, Denver, Colo., $77 \mathrm{p}$.

Wootton, R.J., 1990, Ecology of teleost fishes: London, Chapman and Hall, 404 p. 
